\title{
Phytochemical analysis and versatile in vitro evaluation of antimicrobial, cytotoxic and enzyme inhibition potential of different extracts of traditionally used Aquilegia pubiflora Wall. Ex Royle
}

\author{
Hasnain Jan ${ }^{1 *}$ D, Hazrat Usman ${ }^{1}$, Muzamil Shah', Gouhar Zaman', Sadaf Mushtaq ${ }^{1}$, Samantha Drouet ${ }^{2,3}$,
} Christophe Hano ${ }^{2,3}$ and Bilal Haider Abbasi ${ }^{* *}$

\begin{abstract}
Background: Himalayan Columbine (Aquilegia pubiflora Wall. Ex Royle) is a medicinal plant and have been used as traditional treatments for various human diseases including skin burns, jaundice, hepatitis, wound healing, cardiovascular and circulatory diseases. Till now there is no report available on phytochemical investigation of Himalayan Columbine and to the best of our knowledge, through present study we have reported for the first time, the phytochemical analysis and pharmacological potentials of different leaf extracts of Aquilegia pubiflora.

Methods: Four types of extracts were prepared using solvent of different polarities (Distilled water $A P_{D W}$, Methanol $A P_{M}$, Ethanol $A P_{E}$ and Ethyl acetate $A P_{E A}$, and were evaluated to determine the best candidate for potent bioactivity. Phytochemical constituents in prepared extracts were quantified through HPLC analysis. Subsequently, all four types of leaf extracts were then evaluated for their potential bioactivities including antimicrobial, protein kinase inhibition, anti-inflammatory, anti-diabetic, antioxidant, anti-Alzheimer, anti-aging and cytotoxic effect.

Results: HPLC analysis demonstrated the presence of dvitexin, isovitexin, orientin, isoorientin, ferulic acid, sinapic acid and chlorogenic acid in varied proportions in all plant extracts. Antimicrobial studies showed that, $K$. pneumonia was found to be most susceptible to inhibition zones of $11.2 \pm 0.47,13.9 \pm 0.33,12.7 \pm 0.41$, and $13.5 \pm$ 0.62 measured at $5 \mathrm{mg} / \mathrm{mL}$ for $A P_{D W}, A P_{M}, A P_{E}$ and $A P_{E A}$ respectively. A. niger was the most susceptible strain in case of $A P_{D W}$ with the highest zone of inhibition $14.3 \pm 0.32,13.2 \pm 0.41$ in case of $A P_{M}, 13.7 \pm 0.39$ for $A_{E}$ while $15.4 \pm 0.43$ zone of inhibition was recorded in case of $A P_{E A}$ at $5 \mathrm{mg} / \mathrm{mL}$. The highest antioxidant activity of $92.6 \pm 1.8$ $\mu \mathrm{gAAE} / \mathrm{mg}, 89.2 \pm 2.4 \mu \mathrm{gAAE} / \mathrm{mg}, 277.5 \pm 2.9 \mu \mathrm{M}, 289.9 \pm 1.74 \mu \mathrm{M}$ for TAC, TRP, ABTS and FRAP, respectively, was shown by $A P_{E} . A P_{M}, A P_{E}$ and $A P_{E A}$ extracts showed a significant \% cell inhibition (above 40\%) against HepG2 cells. The highest anti-inflammatory of the samples was shown by $\mathrm{AP}_{E}(52.5 \pm 1.1)$ against $S P L A 2,(41.2 \pm 0.8)$ against 15LOX, followed by $(38.5 \pm 1.5)$ and (32.4 \pm 0.8$)$ against COX-1 and COX-2, respectively.
\end{abstract}

\footnotetext{
* Correspondence: rhasnain849@gmail.com; bhabbasi@qau.edu.pk

'Department of Biotechnology, Quaid-i-Azam University, Islamabad 45320,

Pakistan

Full list of author information is available at the end of the article
}

(c) The Author(s). 2021 Open Access This article is licensed under a Creative Commons Attribution 4.0 International License, which permits use, sharing, adaptation, distribution and reproduction in any medium or format, as long as you give appropriate credit to the original author(s) and the source, provide a link to the Creative Commons licence, and indicate if changes were made. The images or other third party material in this article are included in the article's Creative Commons licence, unless indicated otherwise in a credit line to the material. If material is not included in the article's Creative Commons licence and your intended use is not permitted by statutory regulation or exceeds the permitted use, you will need to obtain permission directly from the copyright holder. To view a copy of this licence, visit http://creativecommons.org/licenses/by/4.0/. The Creative Commons Public Domain Dedication waiver (http://creativecommons.org/publicdomain/zero/1.0/) applies to the data made available in this article, unless otherwise stated in a credit line to the data. 
Conclusions: Strong antimicrobial, Protein Kinase potency and considerable a-glucosidase, a-amylase, and cytotoxic potential were exhibited by plant samples. Significant anti-Alzheimer, anti-inflammatory, anti-aging, and kinase inhibitory potential of each plant sample thus aware us for further detailed research to determine novel drugs.

Keywords: Anti-cancer, HPLC, Flavonoids, Antimicrobial, Anti-aging, Inflammatory,

\section{Background}

Phytochemicals are bioactive chemical compounds, which occur naturally in plants and are primarily responsible for protecting host plant by developing natural immune system, and provide specific aroma, flavor and color to the host plant. Traditionally used medicinal plants have gain ample attention in this era for development of novel drug compounds, as plants derived drugs and remedies have made a huge contribution to human safety, health and well-being [1]. The biologically active compounds derived from medicinal plants have demonstrated a great potential for treating human diseases such as cancer, heart disease, diabetes and infectious diseases [2]. Natural products have influenced several discoveries in organic chemistry, leading to advancement in synthetic methodologies by developing new lead compounds having pharmaceutical or therapeutic potential. Cinchona's approval for treating malaria, preceded by digitalis and morphine and later the advent of aspirin, led the general population to believe in the miracles of natural floral resources [3].

The emergence of antibiotic resistance in some common pathogenic strains has substantially increased in the recent years, due to the consequence of indiscriminate use or misuse of antibiotics, hence results in escalating therapeutic problems [4]. Several medicinal plants and their bioactive products have been tested against antibiotic resistant pathogenic microbes [5]. The use of medicinal plants in food products in the form of bioactive compounds, such as carotenoids, flavonoids, phenolics and terpenoids etc. help to boost natural immunity of the body to fight against microbes [6-8]. These phytochemicals have been reported to perform different biological activities, e.g. anti-cancer [9], antiinflammatory [10], antibacterial [11], anti-viral [12], antiischemic [13] and vasodilator [14].

Many medicinal plants possess large amounts of phytochemicals with antioxidant activities such as polyphenols, having ability to neutralize and quench free radicals, and are capable to decompose peroxides. These significant antioxidant properties possessed by phytochemicals are associated with prevention and treatment of several human disorders [15] Various researches have been conducted to isolate and characterize these compounds responsible for radical scavenging activities, to develop natural antioxidant formulations for cosmetics, medicine, and food industry [16-18].

In traditional medicines large number of medicinal herbs have been tested against inflammatory diseases and many of them are proved to be potent antiinflammatory agents. A vast range of phytochemicals such as saponins, polysaccharides, lignans, anthraquinones, polyphenols, alkaloids, terpenoids, flavonoids are considered responsible for anti-inflammatory potential of the plants $[19,20]$. However, their biochemical investigations has demonstrated that flavonoids are the major class of phytochemicals which acts as potent antiinflammatory agents. The mode of action of different anti-inflammatory agents varies depending upon their chemical structures. Some of them acts as TNF- $\alpha$ inhibitors, while some inhibits phospholipases. It has been investigated that flavonoids blocks metabolism of arachidonic acid by inhibiting lipoxygenase and cyclooxygenase pathways [21, 22].

Several medicinal plants have anti-aging properties and have been used for delaying aging of body cells. Anti-aging potential of medicinal herbs is attributed to their ability to enhance vital energy levels in the body and to provide essential nutrients and modulate several pathological aspects because of their antimicrobial and anti-parasitic activities. Anti-aging medicinal herbs can promote health of all parts of the body including nerve cells and are effective against aging-associated neurological disorders [23-25].

The use of medicinal plants for treating cancer dates back to ancient times. Almost 3000 years ago Chinese practitioners prescribed herbal products as a remedy to cancer patients. The National Cancer Institute (USA) has successfully screened around 114,000 extracts of 35,000 medicinal plant samples collected from 20 countries for cancer treatment [26]. Various anti-cancer plant species have been reported, some of these plants includes Fagonia indica [27], Linum usitatssimum [28], Cannabis sativa, Catharanthus roseus, Curcuma longa, Taxus baccata, Oroxylum indicum, Chelidonium majus, and Curcuma zedoaria etc. [29]. Paclitaxel, a plant derived anti-cancer drug obtained from the bark extract of the Pacific Yew, is an evidence of use of natural plant products in drug discovery [30]. 
Aquilegia publiflora a medicinally important plant belongs to Genus Aquilegia and family ranunculaceae and is commonly known as Himalayan columbine. Plant species belonging to Ranunculaceae family contain pharmacologically important phytochemicals including $p$ coumaric acid, aquilegiolide apigenin, $\beta$ sitosterol, ferulic acid, magnoflorine, resorcylic acid, genkwanin, glochidionolactone and caffeic acid [31-33]. Well known traditional medicinal applications of Aquilegia pubiflora include treatment of skin burns, hepatitis, wound healing, jaundice, circulatory and cardiovascular diseases [34-37].

To the best of our knowledge, it is the first ever report on HPLC analysis of medicinally important plant Aquilegia pubiflora. Different types of leaf extracts (Aqueous, methanol, ethanol and ethyl acetate) of Aquilegia pubiflora were prepared and were investigated for their biological applications.

\section{Methods}

\section{Materials, reagents and strains}

In the current research, all solvents used were of analytical grade and were supplied by Thermo Scientific (Illkirch, France). All reagents and standards were bought from Merck (Saint-Quentin-Fallavier, Lyon, France). Strains including Bacillus subtilis (ATCC 6633), Klebsiella pneumoniae (ATCC 13883), Staphylococcus epidermidis (ATCC 14490), Pseudomonas aeruginosa (ATCC 9721), Escherichia coli (ATCC 15224), Aspergillus flavus (ATCC 9643), Aspergillus fumigatus (FCBP 66), Fusarium solani (FCBP 434), Aspergillus niger (ATCC 1015) and Mucor species (FCBP 300) were acquired from Department of Biotechnology, QAU, Pakistan.

\section{Plant collection and extracts preparation}

In this study the herb Aquilegia pubiflora was obtained from District Swat (Mian Damm), Khyber Pakhtunkhwa, Pakistan. The plant was taxonomically identified by the Department of Botany, Bacha Khan University, Charsadda as Aquilegia Pubiflora and was later confirmed by Professor Mushtaq Ahmad, Department of Plant Sciences, Quaid-i-Azam University Islamabad, Pakistan.

The fresh plant leaves were excised with a sterile surgical blade into tiny pieces, rinsed well under running tap water to eliminate any contaminants and impurities of soil, washed thrice with distilled water and were shade dried. The dried leaves were then ground into fine powder using a Willy mill and were processed for aqueous extraction at $25^{\circ} \mathrm{C}$. Aqueous, methanol, ethanol, and ethyl acetate extracts of plant leaves were prepared separately by adding $25 \mathrm{~g}$ of obtained powder in flasks $(500 \mathrm{~mL})$ comprising $200 \mathrm{~mL}$ of respective solvents, sonicated for $10 \mathrm{~min}$, and were placed at $40{ }^{\circ} \mathrm{C}$ for 2 days in a shaking incubator at
$200 \mathrm{rpm}$. The obtained extracts were initially filtered twice with nylon cloth to remove solid residues and were further filtered thrice using Whatman filter paper to remove any remaining particulates. The fresh filtrate was then dried and processed for further use.

\section{HPLC analysis}

After aqueous extraction the obtained samples were analysed via HPLC using a separation technique adapted from [38]. HPLC standards were purchased from Sigma Aldrich. Here, an Hypersil PEP 300 C18, $250 \times 4.6 \mathrm{~mm}$, $5 \mu \mathrm{m}$ particle size equipped with a guard column Alltech, $10 \times 4.1 \mathrm{~mm}$ was used at $35^{\circ} \mathrm{C}$. Compound detection was achieved at $280 \mathrm{~nm}$. The mobile phase was composed of a mixture of solvent $\mathrm{A}=\mathrm{HCOOH} / \mathrm{H}_{2} \mathrm{O}$, $\mathrm{pH}=2.1$ and solvent $\mathrm{B}=\mathrm{CH}_{3} \mathrm{OH}$ (HPLC grade solvents). The mobile phase composition varied during a $1 \mathrm{~h}$ run, with a nonlinear gradient as follows: $8 \% \mathrm{~B}(0 \mathrm{~min}), 12 \%$ B (11 min), 30\% B (17 min), 33\% B (28 min), 100\% B $(30-35 \mathrm{~min})$ and $8 \% \mathrm{~B}(36 \mathrm{~min})$ at a flow rate of $1 \mathrm{~mL} /$ min. A 10 min re-equilibration was applied between each run. Quantification was based on external 5-point Calibration curves with $R^{2}$ of at least 0.998 using commercial reference standards (Sigma Aldrich). All the samples were analyzed three times and the results were expressed in $\mu \mathrm{g} / \mathrm{mg}$ DW of the sample.

\section{Biological applications Anti-bacterial assay}

Agar disc diffusion method as reported previously [39], was employed to evaluate the antibacterial activity of test samples using concentrations ranging from $0.5 \mathrm{mg} / \mathrm{L}$ to $5 \mathrm{mg} / \mathrm{L}$. Different bacterial strains used in this study include Bacillus subtilis (ATCC 6633), Klebsiella pneumoniae (ATCC 13883), Staphylococcus epidermidis (ATCC 14490), Pseudomonas aeruginosa (ATCC 9721) and Escherichia coli (ATCC 15224). In brief, $50 \mu \mathrm{L}$ of refreshed bacterial cultures were poured onto nutrient agar plates and were spread out uniformly with cotton swabs. Using a sterile borer, wells of $5 \mathrm{~mm}$ size were created, $10 \mu \mathrm{L}$ of the tested samples were added in each well and the plates were labeled accordingly. In this assay, Ampicillin and DMSO were used as positive and negative control, respectively. The bacterial culture plates were then incubated for $24 \mathrm{~h}$ at $37^{\circ} \mathrm{C}$. After the incubation period, zones of inhibition obtained for each bacterial species were measured in $\mathrm{mm}$ using a Vernier caliper.

\section{Anti-fungal assay}

To test the fungicidal activity of prepared plant extracts, the samples were evaluated against five spore forming fungi including Aspergillus flavus (ATCC 9643), Aspergillus fumigatus (FCBP 66), Fusarium solani (FCBP 434), 
Aspergillus niger (ATCC 1015) and Mucor species (FCBP 300 ), respectively. Briefly, the spore suspensions from stock cultures were prepared in Tween 20 solution $(0.02 \% \mathrm{v} / \mathrm{v})$ for each fungal strain. From each aliquot of stock suspension cultures, $100 \mu \mathrm{L}$ volume was poured onto separate petri plates containing sterile SDA media and was swabbed well. Subsequently, tested samples $(10 \mu \mathrm{L})$ were added into each well and the seeded plates were properly labelled. Ampicillin and DMSO were employed as positive and negative controls, respectively. The culture plates were then placed for $48 \mathrm{~h}$ incubation followed by examination and measurement of Zone of Inhibition to the nearest $\mathrm{mm}$, using a Vernier caliper.

\section{Protein kinase inhibition assay}

Protein kinase enzyme inhibition bioassay using different concentrations of prepared extracts ranging from 0.5 $\mathrm{mg} / \mathrm{L}$ to $5 \mathrm{mg} / \mathrm{L}$ was performed following protocol [40] with slight modifications, to verify their protein kinase inhibitory ability, as a preliminary assay to screen the anti-cancerous potential of Aquilegia pubiflora leaf extracts. Briefly, Streptomyces $85 \mathrm{E}$ was employed as a test strain. A volume of $100 \mu \mathrm{L}$ from the refreshed culture of Streptomyces $85 \mathrm{E}$ was added to the plates containing sterile ISP4 medium. Five millimetre size wells were created, filled with plant samples $(5 \mu \mathrm{L})$ and were labeled accordingly. Surfactin and DMSO were employed as positive and negative controls, respectively. Subsequently, the culture plates were incubated at $28^{\circ} \mathrm{C}$ for $48 \mathrm{~h}$. The presence of clear and bald zones around the wells is an indication for inhibition of phosphorylation, mycelia and spore formation. A Vernier caliper was used to measure the zones to the nearest $\mathrm{mm}$. Clear zones show the cytotoxic potential of respective extract sample via killing of the tested strain.

\section{In vitro a-amylase and a-glucosidase inhibition assays}

Both a-amylase and a-glucosidase inhibition bioassays were performed to investigate the anti-diabetic potential of the samples.

\section{a-amylase inhibition assay}

The protocol reported by [41], was followed with minor modifications to evaluate the $\alpha$-amylase inhibition potential of test samples. Ninety-six well microplate was used for this assay. The phosphate buffer $(15 \mu \mathrm{L}), \alpha-$ amylase $(25 \mu \mathrm{L})$, test sample $(10 \mu \mathrm{L})$ and starch $(40 \mu \mathrm{L})$ were added to each well included in the test. The plate was then incubated for $30 \mathrm{~min}$ at $50{ }^{\circ} \mathrm{C}$. Finally, $1 \mathrm{M} \mathrm{HCl}$ $(20 \mu \mathrm{L})$ and $90 \mu \mathrm{L}$ of iodine solution were added into each well. DMSO and acarbose served as negative and positive controls while blank contained buffer solution and starch instead of Aquilegia pubiflora leaf extracts. Absorbance was recorded at $540 \mathrm{~nm}$ using a microplate reader. The inhibition was calculated as percentage using the formula

$\%$ Enzyme inhibition $=\left(\frac{\text { Abs Sample-Abs negative control }}{\text { Abs blank-Abs negative control }}\right) \times 100$

\section{a-glucosidase inhibition assay}

The anti-diabetic potential of extracts was further determined by $\alpha$-glucosidase inhibition bioassay using a previously reported protocol with minute modifications $[42,43]$. In the experiment, $50 \mathrm{~mL}$ of phosphate buffer (pH 6.8) supplemented with 100-mg BSA (bovine serum albumin) was used to dissolve $\alpha$-glucosidase (Saccharomyces cerevisiae, Sigma-Aldrich). Reaction mixtures constituting $10 \mu \mathrm{L}$ of tested sample, phosphate buffer (490 $\mu \mathrm{L} ; \mathrm{pH} 6.8$ ) and $p$-nitrophenyl $\alpha$-D-glucopyranoside $(5 \mathrm{mM} ; 250 \mu \mathrm{L})$ were kept sepatately for incubation at $37^{\circ} \mathrm{C}$ for $5 \mathrm{~min}$. Two hundred fifty microlitre $\alpha$ glucosidase $(0.15 \mathrm{unit} / \mathrm{mL})$ was then added to each mixture followed by incubation for $15 \mathrm{~min}$ at $37^{\circ} \mathrm{C}$. After terminating reaction, by adding $2 \mathrm{~mL} \mathrm{Na}_{2} \mathrm{CO}_{3}(200 \mathrm{mM})$ solution, absorption was recorded using a UV-Vis spectrophotometer at $400 \mathrm{~nm}$. The assay is based on the quantification of $p$-nitrophenol release from $p$-nitrophenyl $\alpha$-D-glucopyranoside. In the experiment, acarbose was employed as a positive control and assay was repeated three times.

$\%$ Enzyme inhibition $=\left(\frac{\text { Abs Sample-Abs negative control }}{\text { Abs blank-Abs negative control }}\right) \times 100$

\section{Antioxidant assays}

\section{Total Antioxidant Capacity determination (TAC)}

The assay reported by [39], was employed to examine the total antioxidant capability of the samples. In the experiment, $100 \mu \mathrm{L}$ of sample was added to the Eppendorf tubes with the help of micropipette. After that, $900 \mathrm{~mL}$ of TAC reagent (0.6-M sulfuric acid, $28 \mathrm{mM}$ sodium phosphate and $4 \mathrm{mM}$ ammonium molybdate, in $50 \mathrm{~mL}$ $\mathrm{dH}_{2} \mathrm{O}$ ) was transferred to Eppendorf tubes containing the tested samples. The reaction mixture was placed in a water bath for incubation at $90^{\circ} \mathrm{C}$ for $2.5 \mathrm{~h}$ followed by cooling at room temperature. The absorbance of the samples was then measured at $630 \mathrm{~nm}$ through a microplate reader. The experiment was performed three times and TAC was expressed as $\mu \mathrm{g}$ ascorbic acid equivalent per milligram of the sample.

\section{Total Reducing Power determination (TRP)}

The procedure reported by [39], was used in triplicate to check the total reducing power of the sample. Each test sample $(100 \mu \mathrm{L})$ along with $400 \mu \mathrm{L}$ of 0.2 Molar phosphate buffer ( $\mathrm{pH}$ 6.6) and potassium ferric cyanide $(1 \%$ $\mathrm{w} / \mathrm{v}$ ) was added to the Eppendorf tubes followed by 
incubation in a water bath at $55^{\circ} \mathrm{C}$ for $30 \mathrm{~min}$. Subsequently, $400 \mu \mathrm{L}$ of trichloroacetic acid $(10 \% \mathrm{w} / \mathrm{v})$ was added to each Eppendorf tube followed by centrifugation for $10 \mathrm{~min}$ at $3000 \mathrm{rpm}$. The supernatant $(140 \mu \mathrm{L})$ of each mixture was poured into corresponding wells of a 96-well plate containing $60 \mu \mathrm{L}$ of ferric cyanide solution $(0.1 \% \mathrm{w} / \mathrm{v})$. The absorbance of the samples was then recorded using a microplate reader at $630 \mathrm{~nm}$. The same procedure, as mentioned earlier was followed both for positive and negative controls. Total reducing power (TRP) of was expressed as ( $\mu \mathrm{g}$ ascorbic acid equivalent) per milligram the tested sample.

\section{Free Radical Scavenging Assay (FRSA)}

The protocol reported previously by [44, 45], was adopted with minor changes. The possible free radical scavenging ability of test samples was investigated for their antioxidant potential using DPPH reagent at concentrations ranging from $12.5 \mu \mathrm{L}$ to $400 \mu \mathrm{L}$. Tested samples $(10 \mu \mathrm{L})$ were added to each well of a 96-well plate. DPPH reagent $(190 \mu \mathrm{L})$ was then transferred to each well having the sample. The plates were incubated in the dark for $60 \mathrm{~min}$ at $37^{\circ} \mathrm{C}$. Ascorbic acid was used as a positive control and DMSO was employed as a negative control. Absorbance of reaction mixture was measured at $515 \mathrm{~nm}$ using a microplate reader and free radical scavenging potential was measured in percentage using the following equation

$$
\text { (\%) } \mathrm{FRSA}=\left(1-\frac{A b s}{A b c}\right) \times 100
$$

Where $A b_{c}$ and $A b_{s}$ indicate the absorbance of the negative control and sample, respectively.

\section{ABTS assay}

ABTS scavenging assay also known as (Trolox antioxidant assay) was tested using [46] protocol with slight modifications. ABTS reaction solution was prepared by combining potassium per sulfate $(2.45 \mathrm{mM})$ with $7 \mathrm{mM}$ ABTS salt in the same proportion followed by $16 \mathrm{~h}$ dark incubation. At $25^{\circ} \mathrm{C}$, the final reaction mixture was prepared by adding test samples in the above prepared mixture and allowed the reaction to proceed by keeping in dark for $15 \mathrm{~min}$. Test samples absorbance was recorded via Microplate Reader (BioTek ELX800) at $734 \mathrm{~nm}$. Trolox and DMSO were used as positive and negative control. The samples' antioxidant potential was represented as TEAC, and assays were performed in triplicate manner.

\section{In vitro $A C h E$ and $B C h E$ inhibition assays}

Antialzheimers activity of plant extracts were measured by their ability to inhibit acetylcholinesterase (AChE;
Sigma "101,292,679: $0.03 \mathrm{U} / \mathrm{mL}$ ) and butyrylcholinesterase (BChE; Sigma "101,303,874: $0.01 \mathrm{U} / \mathrm{mL}$ ). In brief, leaf extracts were dispersed in phosphate buffer saline (PBS) with a concentration ranging from $25 \mu \mathrm{g} / \mathrm{mL}$ to $400 \mu \mathrm{g} /$ $\mathrm{mL}$. A substrate solution was prepared in distilled water that constituted butyrylcholine iodide (BTchI; $0.0005 \mathrm{M}$ ), DTNB (5, 5-dithiobisnitrobenzoic acid; $0.00022 \mathrm{M}$ ), and acetylcholine iodide (ATchI; $0.0005 \mathrm{M}$ ). In the assay, pristine reaction mixture and Galanthamine hydrobromide ( $5 \mathrm{mg} / 0.5 \mathrm{~mL}$ methanol) were used as positive and negative controls, respectively. The principle of the assay is based on ATchI and BTchI hydrolysis by AChE and $\mathrm{BChE}$, respectively, leading to 5- thio-2- nitrobenzoate anion formation that gives a yellow colour when form complexes with DTNB [47]. Finally, the absorbance of the samples was recorded using a UV-VIS spectrophotometer at $412 \mathrm{~nm}$. The percentage enzyme activity and enzyme inhibition activities were calculated as

$$
\begin{aligned}
& \% \text { Enzyme activity }=\left(\frac{V}{V \max }\right) \times 100 \\
& \% \text { Enzyme inhibition }=100-\% \text { Enzyme activity }
\end{aligned}
$$

\section{Anti-inflammatory activities \\ Inhibitory activity against COX-1 and COX-2}

The inhibitory potential of test samples was tested against COX-1 (Ovine kit 701,050 France) and COX-2 (Human kit 701,050 France). Ibuprofen $10 \mu \mathrm{M}$ was used as a positive control and arachidonic acid was used as a substrate at $1.1 \mathrm{mM}$ concentration. Both the COXs were measured by following the manufacturer's instructions on kit. The assay was conducted in triplicate in a 96-well plate. Synergy II reader was used at $590 \mathrm{~nm}$ to check N, $\mathrm{N}, \mathrm{N}^{\prime}, \mathrm{N}^{\prime}$-tetramethyl-p-phenylenediamine in 96-well microplate.

\section{Inhibitory activity against 15-LOX}

The inhibitory potential of plant extracts against 15LOX (760,700 kit, Cayman France) was performed. Nordihydroguaiaretic acid (NDGA) $100 \mu \mathrm{M}$ was used as positive control while $10 \mu \mathrm{M}$ arachidonic acid was taken as a substrate. Lipooxygenation reaction occurs, which produces hydroperoxides whose concentration was measured by soy 15-lipooxygenase standard in $10 \mathrm{mM}$ Tris$\mathrm{HCl}$ buffer at 7.4 $\mathrm{pH}$ filter fitted in the kit. The test samples and enzyme are poured in 96-well plate, incubated for $5 \mathrm{~min}$ and the absorbance was measured at $940 \mathrm{~nm}$ using Synergy II reader (BioTek Instruments, Colmar, France). The inhibitor was added in the enzyme mixture, incubated for $5 \mathrm{~min}$ and absorbance was recorded. Then substrate was added in the preincubated mixture and in last chromogen was added in the mixture and absorbance was measured after 5 min of incubation. 


\section{Inhibitory activity against secretory phospholipase A2 (sPLA2)}

Assay kit (10,004,883, Cayman Chem. Co, Interchim, Montluçon, France) was used to check the inhibitory potential of samples against sPLA2. One point forytfour millimetre diheptanoyl thio-PC and $100 \mu \mathrm{M}$ thiotheramide-PC served as positive control and substrate, respectively. The cleavage of diheptanoyl thioPC ester releases free thiols which were measured by Synergy II reader (BioTek Instruments, Colmar, France) at $420 \mathrm{~nm}$ in a 96-well microplate using DTNB (5-50-dithio-bis-(2-nitrobenzoic acid). The percentage inhibition was calculated as.

$$
\% \text { inhibition }=[(\text { IA-inhibitor }) / \mathrm{IA}] * 100
$$

\section{Anti-aging assay \\ Anti-AGE formation activity}

The inhibitory potential of leaf extracts against Vesperlysine AGEs and Pentosidine AGE formation was measured by the previously described protocol of [48]. For this purpose, BSA (Sigma Aldrich) solution was prepared using $0.5 \mathrm{M}$ glucose (Sigma Aldrich) solution and $0.1 \mathrm{M}$ phosphate buffer ( $\mathrm{pH} 7.4$ ), containing $0.02 \%(\mathrm{w} / \mathrm{v})$ sodium azide. Aquilegia pubiflora leaf extracts were mixed with $20 \mathrm{mg} / \mathrm{mL}$ BSA solution. The reaction mixture was dark incubated for 5 days at $37^{\circ} \mathrm{C}$. VersaFluor fluorometer; Bio-Rad, Marnes-la-Coquette, France set was used to record the amount of fluorescent producedby taking absorbance at $330 \mathrm{~nm}$ of excitation wavelength and $410 \mathrm{~nm}$ emission wavelength, respectively.

\section{Tyrosinase assay}

The previously described method of [49], using L-DOPA ( $5 \mathrm{mM}$; Sigma Aldrich) was used for performing tyrosinase assay. L-DOPA diphenolase substrate was mixed with $10 \mu \mathrm{L}$ of test sample along with sodium phosphate buffer (50 mM, pH 6.8). The final volume of the reaction mixture was raised to $200 \mu \mathrm{L}$ by adding $0.2 \mathrm{mg} / \mathrm{mL}$ of mushroom tyrosinase solution (Sigma Aldrich). The extraction solvent replacing the tested sample was used as control. Microplate reader (BioTek ELX800; BioTek Instruments) was used to trace the reaction processes at $475 \mathrm{~nm}$. Relative to corresponding control tyrosinase effect was expressed as percent inhibition.

\section{Elastase assay}

Porcine pancreatic elastase (Sigma Aldrich) was used for the determination of elastase inhibition. N-Succ-Ala-AlaAla-p-nitroanilide (AAAVPN; Sigma Aldrich) served as a substrate in this experiment. The reaction OD was calculated from the relative conversion of the substrate into $p$ - nitroaniline at $410 \mathrm{~nm}$ using a microplate reader (BioTek ELX800; BioTek Instruments) [50]. The assay was conducted three times and the anti-elastase potential was expressed as a percentage inhibition relative to the corresponding power.

\section{Hyaluronidase assay}

The protocol developed by [51], was used for assessing the hyaluronidase inhibitory potential of test samples. A solution containing hyaluronic acid $(0.03 \%(\mathrm{w} / \mathrm{v}))$ and 1.5 units of hyaluronidase (Sigma Aldrich) was used as a substrate. The precipitation of the undigested form of hyaluronic acid occurred with acid albumin solution $(0.1 \%$ (w/v) BSA). OD was calculated at $600 \mathrm{~nm}$ using a microplate reader (BioTek ELX800; BioTek Instruments, Colmar, France). Relative to the corresponding control the anti-hyaluronidase potential was expressed as a percent inhibition.

\section{Collagenase assay}

Collagenase inhibitory assay was performed following a reported the protocol of [50] with slight modification. [(2-furyl) acryloyl]-Leu-Gly-Pro-Ala (FALGPA; Sigma Aldrich) worked as a substrate in this assay. The decline in FALGPA absorbance was continuously observed for $20 \mathrm{~min}$ by recording $\mathrm{OD}$ at $335 \mathrm{~nm}$ using a microplate reader (BioTek ELX800; BioTek Instruments, Colmar, France). The assay was performed in triplicate manner and relative to control anti-collagenase was shown as percent inhibition.

\section{Anti-leishmanial assay}

The anti-leishmanial potential of the plant extracts was assessed against the amastigote and promastigote cultures of L. tropica KWH23 (Department of Biotechnology IIUI Pakistan) [46, 52]. M199 media having 10\% fetal bovine serum was used for culturing of leishmanial parasites. Leishmania culture at a density of $1 \times 10^{6} \mathrm{cells} / \mathrm{ml}$ was used for the analysis. The activity was performed in a 96well plate with a concentration ranging from 400 to $25 \mu \mathrm{g} /$ mL. DMSO was used as a blank and Amphotericin served as a positive control in the experiment. The seeded 96well plate with test dilutions was incubated at room temperature for $72 \mathrm{~h}$. OD was noted at $540 \mathrm{~nm}$, while all lived cultures were counted using an inverted microscope and their LC50 values were calculated by using Table curve software. Percent inhibition was measured as

$$
\% \text { Inhibition }=\left[1-\left\{\frac{\text { Absorbance of sample }}{\text { Absorbance of control }}\right\}\right] \times 100
$$

\section{Cytotoxicity against HepG2 cell line}

HepG2 cells (ATCC HB-8065) were grown in Dulbecco's Modified Eagle Medium (DMEM) supplemented 
with $10 \%$ of Fetal calf serum (FCS), $100 \mathrm{U} / \mathrm{mL}$ penicillin, $2 \mathrm{mM} \mathrm{L}$-glutamine, $100 \mu \mathrm{g} / \mathrm{mL}$ streptomycin and $1 \mathrm{mM}$ $\mathrm{Na}$-pyruvate and were incubated in a $5 \%$ humified $\mathrm{CO}_{2}$ atmosphere at $37^{\circ} \mathrm{C}$. The confluent cell layer was harvested using $0.5 \mathrm{mM}$ trypsin/EDTA. MTT (3-4, 5dimethylthiazol-2-yl) - 2, 5-diphenyltetrazolium bromide), a tetrazolium dye was used to access the cytotoxic potential of different leaf extracts in vitro. In this assay,, MTT become reduced into its insoluble purple product formazan which is measured spectrophotometrically. In a 96-well plate, pre-seeded HepG2 cells (> 90\% viability; $1 \times 10^{4}$ cells/well or 10,000 cells per well) were treated with $200 \mu \mathrm{g} / \mathrm{mL}$ of test samples for $24 \mathrm{~h}$. Later, $10 \mu \mathrm{L}$ of MTT dye $(5 \mathrm{mg} / \mathrm{mL})$ was added per well, followed by incubation of $3 \mathrm{~h}$. Insoluble formazan was then dissolved by adding $10 \%$ acidified sodium dodecyl sulfate (SDS). Cells were then incubated overnight. Plates were analyzed at $570 \mathrm{~nm}$ using a microplate reader (Platos R 496, AMP). Non-treated HepG2 cells (NTC) were included as control. DMSO was used as a negative control for plant extracts. Optical Density of treated samples and NTC was measured at $570 \mathrm{~nm}$. Percent (\%) viability was calculated relative to the NTC sample using the following formula:

$\%$ Viability $=\frac{\text { Absorbance of sample-Absorbance of sample control }}{\text { Absorance }} \times 100$

\section{Results}

\section{HPLC analysis of different plant extracts}

Genus Aquilegia belongs to the Ranunculaceae family, which has more than 60 species of plants that are used primarily in South Asia and worldwide for many medicinal purposes. These plants have abundant phytochemicals with efficient therapeutic properties [3133]. In this study, Aquilegia publiflora leaf extracts were prepared using four solvents with different polarities. To determine and quantify the specific phytochemicals present in these extracts, highperformance liquid chromatography (HPLC) was performed. Eight compounds, including four flavonoids (vitexin, orientin, isovitexin, and isoorientin) and four derivatives of hydroxycinnamic acid (chlorogenic acid, ferulic, sinapic acid and $p$-coumaric acid) were identified (based on their retention times and UV spectra compared to commercial standards) and quantified for all leaf extracts (Fig. 1). Flavonoids and hydroxycinnamic acids are phenylpropanoids generated via the pathway of shikimic acids and have been correlated with various biological activities of medicinal plants [53]. HPLC results indicated a higher number of flavonoids and derivatives of hydroxycinnamic acid as shown in Table 1. Among the detected flavonoids orientin was observed to be present in a higher concentration for $\mathrm{AP}_{\mathrm{EA}}$ and $\mathrm{AP}_{\mathrm{E}}(171 \pm 2.4 \mu \mathrm{g} / \mathrm{g} \mathrm{DW}$ and $983 \mu \mathrm{g} / \mathrm{g}$ DW respectively) while chlorogenic acid was found to be abundant hydroxycinnamic acid for both $\mathrm{AP}_{\mathrm{EA}}$ and $\mathrm{AP}_{\mathrm{E}}(1.15 \pm 0.08 \mu \mathrm{g} / \mathrm{g}$ DW and $1.70 \mu \mathrm{g} / \mathrm{g}$ DW respectively). Orientin and chlorogenic acid protect the plant from stress conditions and perform various biological activities such as, antioxidant, antiaging, anti-inflammatory, anti-diabetic, antifungal, antibacterial, hepatoprotective and anticancer [54].

\section{Antibacterial activity}

Antibiotic resistance is a serious issue that tends to plague the healthcare system of both emerging and industrialized countries around the globe [55]. The advent and dissemination of multidrug-resistant infections has affected the existing antibacterial treatments greatly. Therefore, a quest for new sources of antimicrobial agents has increased in recent years, to combat with the resistant infectious pathogens. In this context, medicinal plants with antimicrobial potential have been widely explored, as

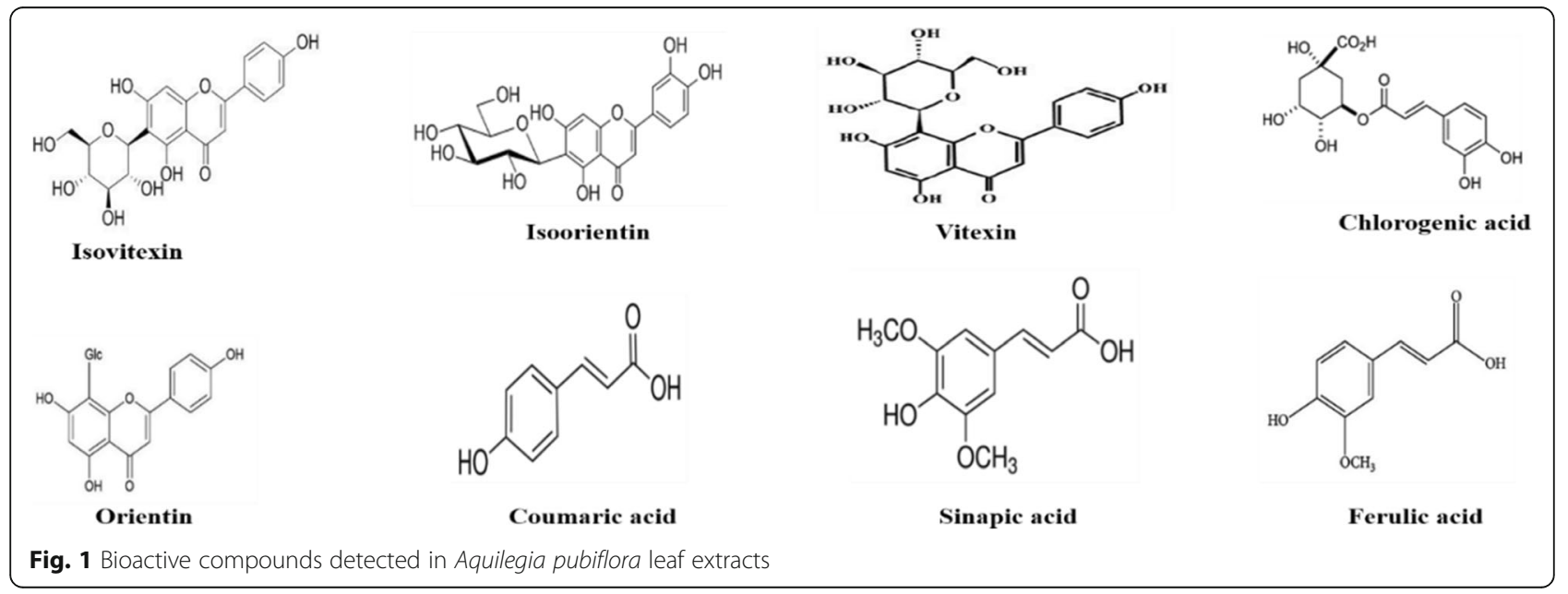


Table 1 HPLC analysis of Aquilegia pubiflora leaf extract in different solvents

\begin{tabular}{|c|c|c|c|c|}
\hline Phytochemicals & $A P_{D W}(\mu g / g D W)$ & $A P_{M}(\mu g / g D W)$ & $\mathrm{AP}_{\mathrm{E}}(\mu \mathrm{g} / \mathrm{g} \mathrm{DW})$ & $A P_{E A}(\mu g / g D W)$ \\
\hline \multicolumn{5}{|l|}{ FLAVONOIDS } \\
\hline Orientin & $72.56 \pm 3.09$ & $63.30 \pm 2.7$ & $983 \pm 4.3$ & $171 \pm 2.4$ \\
\hline Isoorientin & $54.03 \pm 2.02$ & $37.05 \pm 1.6$ & $483.79 \pm 4.1$ & $97.33 \pm 1.90$ \\
\hline Isovitexin & $16.982 \pm 2.65$ & $7.719 \pm 0.63$ & $161.78 \pm 2.9$ & $48.27 \pm 1.1$ \\
\hline Vitexin & $92.63 \pm 3.71$ & $58.66 \pm 1.91$ & $489.96 \pm 3.8$ & $86.23 \pm 1.21$ \\
\hline \multicolumn{5}{|c|}{ HYROXYCINNAMIC ACIDS } \\
\hline p-Coumaric acid & $0.069 \pm 0.011$ & $0.049 \pm 0.007$ & $0.31 \pm 0.3$ & $0.26 \pm 0.2$ \\
\hline Ferulic acid & $0.145 \pm 0.014$ & $0.076 \pm 0.006$ & $0.52 \pm 0.7$ & $0.44 \pm 0.5$ \\
\hline Sinapic acid & $0.049 \pm 0.007$ & $0.038 \pm 0.007$ & $0.20 \pm 0.4$ & $0.16 \pm 0.3$ \\
\hline Chlorogenic acid & $0.355 \pm 0.13$ & $0.280 \pm 0.006$ & $1.70 \pm 0.11$ & $1.15 \pm 0.08$ \\
\hline
\end{tabular}

they contain a range of bioactive compounds with proven therapeutic properties [56-58]. This study was aimed to evaluate the antimicrobial activity of medicinal plant Aquilegia pubiflora extracts against five pathogenic bacteria, including 2 Gram-positive (Staphylococcus epidermidis and Bacillus subtilis) and 3 Gram-negative (Escherichia coli, Klebsiella pneumoniae, and Pseudomonas aeruginosa) using well disc diffusion method. These organisms were frequently encountered in infectious diseases [59]. The research demonstrated that all plant extracts used had varied degrees of antimicrobial activity against all microorganisms tested at five different concentrations $(5 \mathrm{mg} / \mathrm{mL}$, $4 \mathrm{mg} / \mathrm{mL}, 2 \mathrm{mg} / \mathrm{mL}, 1 \mathrm{mg} / \mathrm{mL}$, and $0.5 \mathrm{mg} / \mathrm{mL})$. All the tested strains were susceptible to all extracts shown in (Table 2) with K. pneumonia is found to be most susceptible. Inhibition zones measured at $5 \mathrm{mg} / \mathrm{mL}$ for $\mathrm{AP}_{\mathrm{DW}}, \mathrm{AP}_{\mathrm{M}}, \mathrm{AP}_{\mathrm{E}}$ and $\mathrm{AP}_{\mathrm{EA}}$ were $11.2 \pm 0.47,13.9 \pm$ $0.33, \quad 12.7 \pm 0.41$, and $13.5 \pm 0.62$ for Klebsiella

Table 2 Zones of inhibitions of plant extracts against bacterial strains at different concentrations

\begin{tabular}{|c|c|c|c|c|c|c|c|}
\hline \multirow[t]{3}{*}{ Bacterial Strains } & \multirow[t]{3}{*}{ Sample } & \multicolumn{6}{|c|}{ Concentration } \\
\hline & & Ampicillin & $5 \mathrm{mg} / \mathrm{mL}$ & $4 \mathrm{mg} / \mathrm{mL}$ & $2 \mathrm{mg} / \mathrm{mL}$ & $1 \mathrm{mg} / \mathrm{mL}$ & $0.5 \mathrm{mg} / \mathrm{mL}$ \\
\hline & & \multicolumn{6}{|c|}{ Zone of inhibition in (mm) } \\
\hline \multirow[t]{4}{*}{ Bacillus subtilis } & $A P_{D W}$ & $15.4 \pm 0.67$ & $10.1 \pm 0.20^{*}$ & $8.2 \pm 0.31^{* *}$ & $8.1 \pm 0.27^{* *}$ & $6.4 \pm 0.19^{* * *}$ & $5.7 \pm 0.19^{* * *}$ \\
\hline & $\mathrm{AP}_{\mathrm{M}}$ & $17.1 \pm 0.74$ & $12.1 \pm 0.38^{*}$ & $11.7 \pm 0.34^{*}$ & $10.2 \pm 0.29^{* *}$ & $7.3 \pm 0.24^{* * *}$ & $6.2 \pm 0.17^{* * *}$ \\
\hline & $A P_{E}$ & $15.8 \pm 0.72$ & $12.2 \pm 0.39^{*}$ & $9.3 \pm 0.32^{*}$ & $6.9 \pm 0.22^{* *}$ & $6.1 \pm 0.18^{* *}$ & $4.7 \pm 0.21^{* * *}$ \\
\hline & $A P_{E A}$ & $15.5 \pm 0.69$ & $10.7 \pm 0.43^{*}$ & $9.7 \pm 0.26^{*}$ & $6.3 \pm 0.21^{* *}$ & $5.7 \pm 0.19^{* * *}$ & $5.2 \pm 0.31^{* * *}$ \\
\hline \multirow[t]{4}{*}{ Staphylococcus epidermidis } & $A P_{D W}$ & $16.4 \pm 0.59$ & $10.3 \pm 0.27^{*}$ & $10.1 \pm 0.39^{*}$ & $7.3 \pm 0.19^{* *}$ & $6.2 \pm 0.25^{* *}$ & $4.4 \pm 0.17^{* * *}$ \\
\hline & $\mathrm{AP}_{\mathrm{M}}$ & $17.3 \pm 0.57$ & $10.4 \pm 0.22^{*}$ & $8.6 \pm 0.29^{*}$ & $6.9 \pm 0.24^{* *}$ & $5.2 \pm 0.17^{* * *}$ & $4.1 \pm 0.18^{* * *}$ \\
\hline & $A P_{E}$ & $15.4 \pm 0.40$ & $12.3 \pm 0.21^{*}$ & $10.2 \pm 0.44^{* *}$ & $10.2 \pm 0.37^{* *}$ & $8.3 \pm 0.31^{* *}$ & $5.4 \pm 0.24^{* * *}$ \\
\hline & $A P_{E A}$ & $14.8 \pm 0.38$ & $11.3 \pm 0.39^{*}$ & $8.4 \pm 0.31^{*}$ & $6.6 \pm 0.28^{* *}$ & $6.2 \pm 0.19^{* *}$ & $4.8 \pm 0.17^{* * *}$ \\
\hline \multirow[t]{4}{*}{ Klebsiella pneumoniae } & $A P_{D W}$ & $15.9 \pm 0.33$ & $11.2 \pm 0.47^{*}$ & $10.7 \pm 0.42^{*}$ & $8.3 \pm 0.37^{* *}$ & $7.1 \pm 0.29^{* *}$ & $5.4 \pm 0.19^{* * *}$ \\
\hline & $\mathrm{AP}_{\mathrm{M}}$ & $16.9 \pm 0.61$ & $13.9 \pm 0.33^{*}$ & $11.4 \pm 0.45^{*}$ & $9.1 \pm 0.33^{* *}$ & $6.9 \pm 0.32^{* * *}$ & $6.2 \pm 0.23^{* * *}$ \\
\hline & $\mathrm{AP}_{\mathrm{E}}$ & $15.6 \pm 0.39$ & $12.7 \pm 0.41^{*}$ & $10.6 \pm 0.39^{*}$ & $7.7 \pm 0.32^{* *}$ & $5.8 \pm 0.27^{* * *}$ & $5.2 \pm 0.22^{* * *}$ \\
\hline & $A P_{E A}$ & $15.2 \pm 0.34$ & $13.5 \pm 0.62^{*}$ & $12.2 \pm 0.53^{*}$ & $9.4 \pm 0.32^{*}$ & $8.1 \pm 0.29^{* *}$ & $6.7 \pm 0.28^{* *}$ \\
\hline \multirow[t]{4}{*}{ Escherichia coli } & $A P_{D W}$ & $15.7 \pm 0.41$ & $10.8 \pm 0.31^{*}$ & $8.3 \pm 0.31^{*}$ & $7.0 \pm 0.19^{* *}$ & $6.3 \pm 0.16^{* *}$ & $4.8 \pm 0.19^{* * *}$ \\
\hline & $\mathrm{AP}_{\mathrm{M}}$ & $17.2 \pm 0.66$ & $12.9 \pm 0.59^{*}$ & $12.1 \pm 0.51^{*}$ & $9.5 \pm 0.35^{*}$ & $7.1 \pm 0.28^{* *}$ & $5.4 \pm 0.19^{* * *}$ \\
\hline & $\mathrm{AP}_{\mathrm{E}}$ & $15.9 \pm 0.54$ & $12.6 \pm 0.29^{*}$ & $11.2 \pm 0.49^{*}$ & $8.4 \pm 0.28^{* *}$ & $6.7 \pm 0.24^{* * *}$ & $6.0 \pm 0.21^{* * *}$ \\
\hline & $A P_{E A}$ & $15.5 \pm 0.48$ & $11.7 \pm 0.31^{*}$ & $10.3 \pm 0.34^{*}$ & $9.2 \pm 0.19^{*}$ & $7.2 \pm 0.21^{* *}$ & $5.1 \pm 0.22^{* * *}$ \\
\hline \multirow[t]{4}{*}{ Pseudomonas aeruginosa } & $A P_{D W}$ & $16.2 \pm 0.46$ & $11.1 \pm 0.29^{*}$ & $9.2 \pm 0.47^{*}$ & $7.7 \pm 0.43^{* *}$ & $5.9 \pm 0.28^{* * *}$ & $4.3 \pm 0.21^{* * *}$ \\
\hline & $\mathrm{AP}_{\mathrm{M}}$ & $16.3 \pm 0.57$ & $13.6 \pm 0.61^{*}$ & $10.1 \pm 0.33^{*}$ & $10.4 \pm 0.28^{*}$ & $8.4 \pm 0.29^{* *}$ & $6.9 \pm 0.21^{* *}$ \\
\hline & $A P_{E}$ & $15.4 \pm 0.44$ & $12.1 \pm 0.29^{*}$ & $11.3 \pm 0.41^{*}$ & $8.4 \pm 0.44^{*}$ & $6.1 \pm 0.32^{* *}$ & $4.8 \pm 0.19^{* * *}$ \\
\hline & $A P_{E A}$ & $15.9 \pm 0.41$ & $11.1 \pm 0.22^{*}$ & $9.9 \pm 0.33^{* *}$ & $7.4 \pm 0.39^{* *}$ & $7.1 \pm 0.27^{* *}$ & $5.4 \pm 0.19^{* * *}$ \\
\hline
\end{tabular}

Star **** represent; ${ }^{* * *}$ highly significant, ${ }^{* *}$ slightly significant and * non-significant difference from control at $P<0.05$ by one-way ANOVA in the column. Values are mean $\pm S D$ of triplicate. Where $A P_{D W}, A P_{M}, A P_{E}$ and $A P_{E A}$ stands for Distilled water, Methanol, Ethanol and Ethyl acetate extracts, respectively 
pneumoniae, respectively. Our findings was close to that of previous studies that documented antibacterial activity of methanolic extract of O. corniculata [60]. $\mathrm{AP}_{\mathrm{DW}}$ and $\mathrm{AP}_{\mathrm{E}}$ inhibited S. epidermidis and $E$. coli at concentration-dependent manner however, highest zone of inhibition was observed against $S$. epidermidis $(12.3 \pm 0.21)$ and $E$. coli $(12.6 \pm 0.29)$ for $\mathrm{AP}_{\mathrm{E}}$ at $5 \mathrm{mg} /$ $\mathrm{mL}$, respectively. In another study, aqueous and ethanolic extract from C. tamala plant was found to have the same antimicrobial activity against the tested bacterium, S. aureus and K. pneumoniae [61]. Furthermore, E. coli was the most susceptible strain to $\mathrm{AP}_{\mathrm{EA}}$ with significant zone of inhibition $(11.7 \pm 0.31)$ followed by $S$. epidermidis $(11.3 \pm 0.39)$ at $5 \mathrm{mg} / \mathrm{mL}$ concentration.

\section{Antifungal assay}

The anti-fungal activity of plants may be attributed to the presence of antifungal toxicants in their extracts. The fungicidal behavior has also been documented by several authors in a large variety of taxa. The existence of antifungal compounds in higher plants is well known and considered useful for preventing plant diseases [62]. Five pathogenic fungal strains (A. fumigatus, A. flavus, M. racemosus, F. solani and A. niger) were tested against Aquilegia pubiflora leaf extracts using the well diffusion method at concentrations in the range of $0.5 \mathrm{mg} / \mathrm{mL}$ to $5 \mathrm{mg} / \mathrm{mL}$. The results presented in Table 3, clearly demonstrated that $A$. niger was the most susceptible strain in case of $\mathrm{AP}_{\mathrm{DW}}$ with the highest zone of inhibition $14.3 \pm 0.32,13.2 \pm 0.41$ in case of $\mathrm{AP}_{\mathrm{M}}, 13.7 \pm 0.39$ for $\mathrm{AP}_{\mathrm{E}}$ while $15.4 \pm 0.43$ zone of inhibition was recorded in case of $\mathrm{AP}_{\mathrm{EA}}$ at 5 $\mathrm{mg} / \mathrm{mL}$, respectively. Previously, plant extracts from Ageratum conyzoides were found to have the same antifungal activity against the tested fungal specie [63]. Furthermore, these extracts $\left(\mathrm{AP}_{\mathrm{E}}\right.$ and $\left.\mathrm{AP}_{\mathrm{EA}}\right)$ showed impressive fungicidal activity of $(13.2 \pm 0.52$ and $14.8 \pm 0.40$ ) as shown in (Table 3), against $F$. solani at $5 \mathrm{mg} / \mathrm{mL}$ concentration. These obtained results are in accordance with the previously reported studies that revealed efficient antifungal activity of plant extracts [64]. Among the tested strains, A. flavus and $M$. racemosus were less inhibited strains in case of $\mathrm{AP}_{\mathrm{M}}$ and $\mathrm{AP}_{\mathrm{E}}$ at all concentrations. Plant extract $\mathrm{AP}_{\mathrm{DW}}$ seemed to be effective against $M$. racemosus, F. Solani and A. flavus with zone of inhibition $14.1 \pm 0.32,13.8 \pm 0.71$ and $13.2 \pm 0.52$, respectively. In a conclusion, all types of leaf extracts have exhibited

Table 3 Zones of inhibitions of plant extracts against fungal strains at different concentrations

\begin{tabular}{|c|c|c|c|c|c|c|c|}
\hline \multirow[t]{3}{*}{ Fungal Strains } & \multirow[t]{3}{*}{ Sample } & \multicolumn{6}{|c|}{ Concentration } \\
\hline & & Ampicillin & $5 \mathrm{mg} / \mathrm{mL}$ & $4 \mathrm{mg} / \mathrm{mL}$ & $2 \mathrm{mg} / \mathrm{mL}$ & $1 \mathrm{mg} / \mathrm{mL}$ & $0.5 \mathrm{mg} / \mathrm{mL}$ \\
\hline & & \multicolumn{6}{|c|}{ Zone of inhibition in ( $\mathrm{mm})$} \\
\hline \multirow[t]{4}{*}{ Aspergillus niger } & $A P_{D W}$ & $18.1 \pm 0.73$ & $14.3 \pm 0.32^{*}$ & $10.2 \pm 0.42^{*}$ & $7.4 \pm 0.25^{* *}$ & $5.3 \pm 0.21^{* * *}$ & $4.1 \pm 0.19^{* * *}$ \\
\hline & $A P_{M}$ & $17.6 \pm 0.74$ & $13.2 \pm 0.41^{*}$ & $11.3 \pm 0.31^{*}$ & $8.1 \pm 0.28^{*}$ & $6.4 \pm 0.19^{* *}$ & $5.2 \pm 0.31^{* * *}$ \\
\hline & $\mathrm{AP}_{\mathrm{E}}$ & $17.7 \pm 0.61$ & $13.7 \pm 0.39^{*}$ & $9.6 \pm 0.51^{*}$ & $6.8 \pm 0.37^{* *}$ & $4.8 \pm 0.27^{* * *}$ & $4.0 \pm 0.31^{* * *}$ \\
\hline & $A P_{E A}$ & $19.4 \pm 0.43$ & $15.4 \pm 0.43^{*}$ & $11.3 \pm 0.52^{*}$ & $7.7 \pm 0.31^{* *}$ & $6.9 \pm 0.22^{* *}$ & $5.7 \pm 0.21^{* * *}$ \\
\hline \multirow[t]{4}{*}{ Aspergillus fumigatus } & $A P_{D W}$ & $17.4 \pm 0.59$ & $13.5 \pm 0.45^{*}$ & $12.2 \pm 0.44^{*}$ & $9.3 \pm 0.33^{*}$ & $7.1 \pm 0.28^{* *}$ & $6.3 \pm 0.19^{* *}$ \\
\hline & $\mathrm{AP}_{\mathrm{M}}$ & $17.9 \pm 0.57$ & $12.7 \pm 0.32^{*}$ & $9.4 \pm 0.23^{* *}$ & $6.4 \pm 0.26^{* *}$ & $5.1 \pm 0.21^{* * *}$ & $4.7 \pm 0.21^{* * *}$ \\
\hline & $A P_{E}$ & $17.4 \pm 0.40$ & $13.0 \pm 0.66^{*}$ & $10.7 \pm 0.57^{*}$ & $8.5 \pm 0.34^{* *}$ & $6.4 \pm 0.24^{* * *}$ & $6.0 \pm 0.21^{* * *}$ \\
\hline & $\mathrm{AP}_{\mathrm{EA}}$ & $19.8 \pm 0.38$ & $14.2 \pm 0.61^{*}$ & $11.9 \pm 0.51^{*}$ & $8.7 \pm 0.39^{* *}$ & $6.3 \pm 0.21^{* *}$ & $4.9 \pm 0.21^{* * *}$ \\
\hline \multirow[t]{4}{*}{ Fusarium solani } & $A P_{D W}$ & $17.9 \pm 0.33$ & $13.8 \pm 0.71^{*}$ & $12.1 \pm 0.34^{*}$ & $7.4 \pm 0.22^{* *}$ & $6.1 \pm 0.17^{* *}$ & $5.3 \pm 0.28^{* * *}$ \\
\hline & $\mathrm{AP}_{\mathrm{M}}$ & $18.1 \pm 0.61$ & $12.9 \pm 0.61^{*}$ & $9.6 \pm 0.32^{*}$ & $6.3 \pm 0.21^{* *}$ & $4.8 \pm 0.27^{* * *}$ & $4.3 \pm 0.19^{* * *}$ \\
\hline & $\mathrm{AP}_{\mathrm{E}}$ & $16.2 \pm 0.52$ & $13.2 \pm 0.52^{*}$ & $11.4 \pm 0.51^{*}$ & $7.7 \pm 0.29^{* *}$ & $6.3 \pm 0.22^{* *}$ & $3.8 \pm 0.16^{* * *}$ \\
\hline & $\mathrm{AP}_{\mathrm{EA}}$ & $18.8 \pm 0.40$ & $14.8 \pm 0.40^{*}$ & $12.1 \pm 0.47^{*}$ & $9.1 \pm 0.41^{*}$ & $6.6 \pm 0.28^{* * *}$ & $5.1 \pm 0.21^{* * *}$ \\
\hline \multirow[t]{4}{*}{ Mucor racemosus } & $A P_{D W}$ & $18.7 \pm 0.41$ & $14.1 \pm 0.32^{*}$ & $12.3 \pm 0.29^{*}$ & $6.9 \pm 0.38^{* *}$ & $4.6 \pm 0.21^{* * *}$ & $3.7 \pm 0.18^{* * *}$ \\
\hline & $\mathrm{AP}_{\mathrm{M}}$ & $17.7 \pm 0.66$ & $12.6 \pm 0.49^{*}$ & $11.1 \pm 0.39^{*}$ & $8.3 \pm 0.31^{* *}$ & $6.8 \pm 0.28^{* * *}$ & $5.2 \pm 0.19^{* * *}$ \\
\hline & $A P_{E}$ & $17.9 \pm 0.54$ & $13.2 \pm 0.54^{*}$ & $9.9 \pm 0.49^{*}$ & $7.2 \pm 0.32^{*}$ & $5.8 \pm 0.27^{* *}$ & $4.4 \pm 0.21^{* * *}$ \\
\hline & $\mathrm{AP}_{\mathrm{EA}}$ & $18.5 \pm 0.48$ & $13.9 \pm 0.39^{*}$ & $11.2 \pm 0.51^{*}$ & $9.1 \pm 0.30^{*}$ & $6.6 \pm 0.27^{* *}$ & $4.1 \pm 0.19^{* * *}$ \\
\hline \multirow[t]{4}{*}{ Aspergillus flavus } & $A P_{D W}$ & $18.2 \pm 0.64$ & $13.2 \pm 0.52^{*}$ & $10.8 \pm 0.49^{*}$ & $8.2 \pm 0.33^{* *}$ & $6.9 \pm 0.31^{* * *}$ & $5.1 \pm 0.28^{* * *}$ \\
\hline & $\mathrm{AP}_{\mathrm{M}}$ & $18.4 \pm 0.72$ & $12.0 \pm 0.59^{*}$ & $8.9 \pm 0.37^{* *}$ & $6.7 \pm 0.22^{* *}$ & $6.2 \pm 0.18^{* *}$ & $3.8 \pm 0.16^{* * *}$ \\
\hline & $A P_{E}$ & $18.1 \pm 0.40$ & $12.4 \pm 0.51^{*}$ & $9.1 \pm 0.34^{*}$ & $7.4 \pm 0.29^{* *}$ & $5.4 \pm 0.23^{* * *}$ & $5.4 \pm 0.17^{* * *}$ \\
\hline & $\mathrm{AP}_{\mathrm{EA}}$ & $19.2 \pm 0.74$ & $13.0 \pm 0.37^{*}$ & $10.3 \pm 0.29^{*}$ & $7.1 \pm 0.22^{* *}$ & $5.6 \pm 0.26^{* * *}$ & $4.1 \pm 0.18^{* * *}$ \\
\hline
\end{tabular}

Star *_*** represent; *** highly significant, ${ }^{* *}$ slightly significant and ${ }^{*}$ non-significant difference from control at $P<0.05$ by one-way ANOVA in the column. Values are mean $\pm S D$ of triplicate. Where $A P_{D W}, A P_{M}, A P_{E}$ and $A P_{E A}$ stands for Distilled water, Methanol, Ethanol and Ethyl acetate extracts, respectively 
efficient fungicidal activity against fungal strains $A$. niger, $M$. racemosus and $F$. solani at concentrationdependent manner.

\section{Protein kinase inhibition assay}

Protein kinase inhibitors are a well-established class of clinically useful drugs, particularly for treating cancer [65]. For particular protein kinases, achieving inhibitor selectivity remains a significant challenge, in order to use them as a tool for chemical biology research or in the development of new small molecules as drugs [66, 67]. These enzymes phosphorylate serine-threonine and tyrosine amino acid residues that have a key function in cellular proliferation, differentiation and apoptosis [68]. Deregulated phosphorylation by protein kinase can lead to tumor growth and entities with capability to inhibit these enzymes, are important area in anticancer research [69]. Streptomyces $85 \mathrm{E}$ strain was used to check the protein kinase inhibition potential of Aquilegia pubiflora extracts. Results as indicated in Fig. 2a showed that no clear zones were observed against each tested concentration of prepared extracts. Comparatively, $\mathrm{AP}_{\mathrm{E}}$ showed the largest bald zone $14.6 \pm 0.69$ than $\mathrm{AP}_{\mathrm{M}} 14.1 \pm 0.35$, $\mathrm{AP}_{\mathrm{DW}} 13.8 \pm 0.31$ and $\mathrm{AP}_{\mathrm{EA}} 13.2 \pm 0.29$ at $5 \mathrm{mg} / \mathrm{mL}$. Lowest $5.3 \pm 0.21$ zone appeared in case of $\mathrm{AP}_{\mathrm{DW}} 0.5$ $\mathrm{mg} / \mathrm{mL}$ representing least potential against Streptomyces hyphae growth. All the tested plant extracts inhibited Streptomyces strain at concentration-dependent manner as indicated in Fig. 2a. Overall, results showed that the entire test samples acquire vital metabolites responsible for anti-cancerous potentials in Aquilegia pubiflora. Our results are strongly supported by a previous report, which was conducted on the evaluation of hyphae formation inhibition in Streptomyces 85E. The isolated compounds in this reported study had showen impressive zone of inhibition at $80 \mu \mathrm{g} /$ disk and it was hypothesized that the compounds prevent the formation of hyphae in Streptomyces $85 \mathrm{E}$, which may inhibit cancer proliferation [70].

\section{In vitro a-amylase and a-glucosidase inhibition assays}

Diabetes is a lifelong systemic disease induced by insulin secretion deficiency. Type 2 diabetes is more common of the two groups [71]. Some therapies used for treatment of type 2 diabetes includes the regulation of blood sugar and it can be achieved by preventing the absorption of glucose by inhibiting the enzymatic action of $\alpha$ glucosidase and pancreatic $\alpha$-amylase [72, 73]. Natural products, particularly plant products, are the key quarry for the discovery of promising lead candidates and play an imperative role in the upcoming drug development programs, mainly in the field of diabetes and cancer [74]. Ease of delivery, low expense and least side effects render plant-based preparations as themost accessible therapies, especially in rural areas [75]. In fact, many plants have a rich supply of bioactive chemicals, free of undesirable side effects and have effective pharmacological potential against diabetes [76, 77]. Plants have always long been an excellent source of medicines, with many medications commonly available are derived from them explicitly or indirectly. In vitro cellfree $\alpha$-amylase and $\alpha$-glucosidase inhibition assays in a concentration range of 25 to $400 \mu \mathrm{g} / \mathrm{mL}$ were performed to study the anti-diabetic potential of

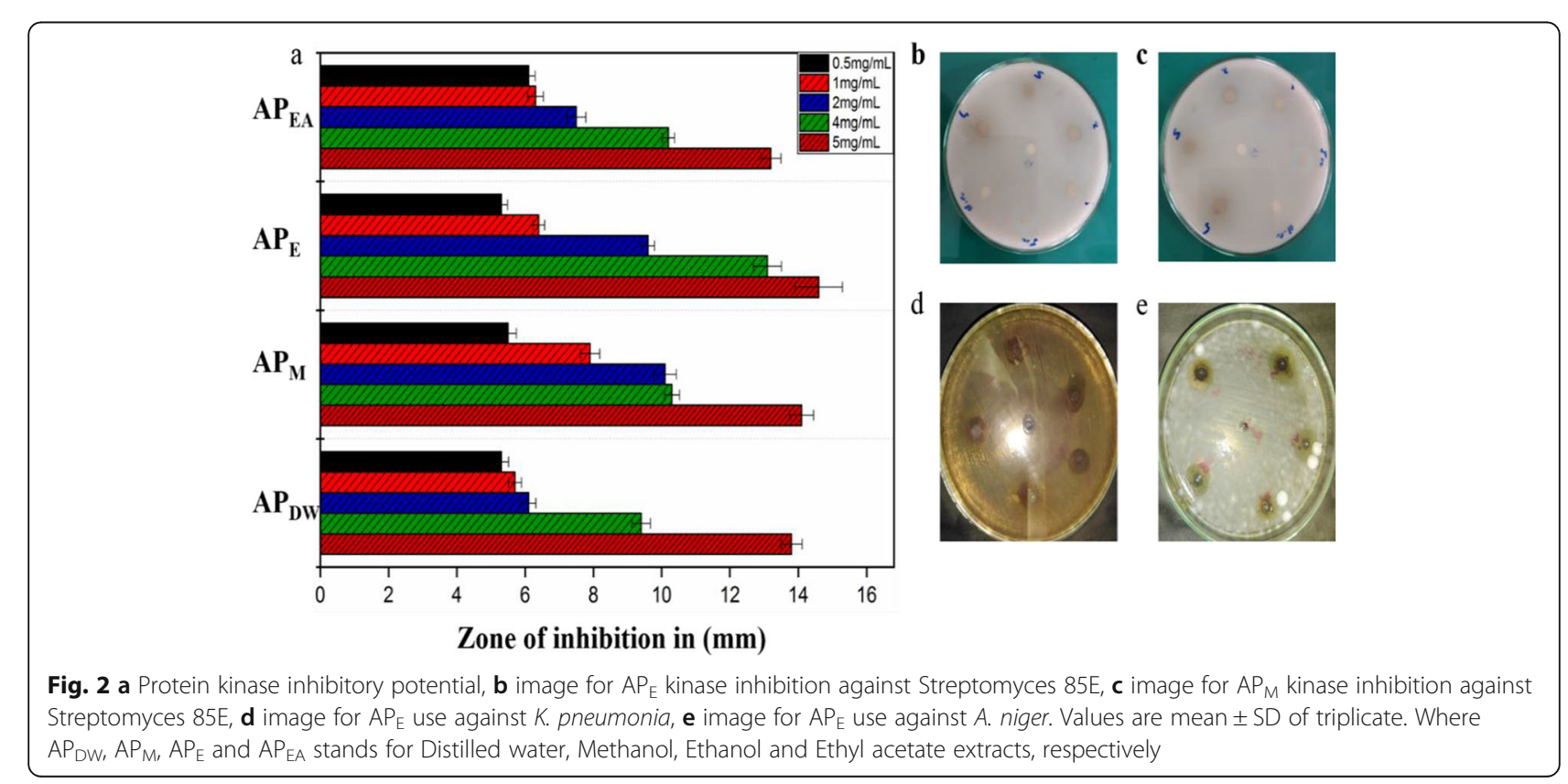


Aquilegia pubiflora leaf extracts. $\mathrm{AP}_{\mathrm{E}}$ has a greater efficiency against $\alpha$-glucosidase $(47.23 \pm 0.41)$ and $\alpha$ amylase $(55.38 \pm 0.73)$ inhibition compared to $\mathrm{AP}_{\mathrm{DW}}$ ( $\alpha$-glucosidase: $34.14 \pm 0.44$ inhibition and $\alpha$-amylase: $37.43 \pm 0.65$ inhibition) and $\mathrm{AP}_{\mathrm{M}}$ ( $\alpha$-glucosidase: $24.63 \pm 0.32$ inhibition and $\alpha$-amylase: $29.31 \pm 0.48$ inhibition) Table 4. For each experiment, acarbose $(10 \mu \mathrm{M})$, the most commonly used therapeutic inhibitor, was used as a positive control. Our results are in harmony with previous reports $[78,79]$.

\section{Antioxidant assay}

The changes occurred in plant metabolic pathways are attributed to environmental stresses that results in production of reactive oxygen species (ROS), that can destroy membrane lipids, DNA, proteins and plant cells [80]. Plants produce numerous metabolic compounds such as flavonoids, terpenoids and oxidative stress response phenolics that act as protective mechanism against these stresses [81, 82]. This paper investigated the antioxidant ability of plant extracts by using four antioxidant assays i.e., TAC (total antioxidant capacity is based on the conversion of Mo (VI) to Mo (V) by the test material), FRAP (ferric reducing activity) assay (ETbased antioxidant activity), ABTS (2,2-azinobis-3-ethylbenzthiazoline-6-sulphonic acid) assay and TRP (total reducing power) assay as exhibited in (Table 5). Value for TAC and TRP were measured in terms of ascorbic acid equivalents of the test sample ( $\mu \mathrm{g} \mathrm{AAE} / \mathrm{mg}$ ), whereas the FRAP and ABTS activities were indicated as TEAC (trolox $C$ equivalent antioxidant capacity, $\mu \mathrm{M}$ ). The highest TAC $(111.6 \pm 2.9 \% \mu \mathrm{gAAE} / \mathrm{mg})$ was shown by $\mathrm{AP}_{\mathrm{M}}$ followed by $\mathrm{AP}_{\mathrm{EA}}(97.4 \pm 1.3 \mu \mathrm{gAAE} / \mathrm{mg})$ at $400 \mu \mathrm{g} / \mathrm{mL}$. The ABTS of $\mathrm{AP}_{\mathrm{E}}$ was $(277.5 \pm 2.9 \mu \mathrm{gAAE} /$ $\mathrm{mg})$ followed by $\mathrm{AP}_{\mathrm{DW}} \quad(213.7 \pm 3.1 \mu \mathrm{gAAE} / \mathrm{mg})$.
Similarly, the TRP was measured, where the highest value of $(89.2 \pm 2.4 \mu \mathrm{gAAE} / \mathrm{mg})$ was shown by $\mathrm{AP}_{\mathrm{E}}$ followed by the $\mathrm{AP}_{\mathrm{DW}}(86.3 \pm 2.1 \mu \mathrm{gAAE} / \mathrm{mg})$. Also, the FRAP activity showed the same trend where the $\mathrm{AP}_{\mathrm{E}}$ has the highest value of $289.9 \pm 2.9 \mu \mathrm{M}$, followed by $\mathrm{AP}_{\mathrm{EA}}$ $245.1 \pm 3.8 \mu \mathrm{M}, \mathrm{AP}_{\mathrm{DW}} 221.4 \pm 4.1 \mu \mathrm{M}$ and $\mathrm{AP}_{\mathrm{M}} 198.6 \pm$ $3.3 \mu \mathrm{M}$, respectively. The antioxidant properties exhibited by leaf extracts may be correlated with the presence of secondary metabolites in plants extracts. Our results match with previous reports [83-85].

\section{In vitro $A C h E$ and $B C h E$ inhibition assays}

Alzheimer's disease (AD) is a progressive neurodegenerative disease contributing to $60-80 \%$ of dementia cases worldwide. The disease is characterized by gradual decline in cognitive abilities such as memory, executive and visual spatial functioning, personality and language [86]. The prevalence rate of the disease is alarming and in United States alone a person develops AD every $65 \mathrm{~s}$ [87]. Current treatments available for AD includes cholinesterase inhibitors for patients with any stage of $\mathrm{AD}$. Diverse synthetic and natural substances have been reported for the effective inhibition of cholinesterase enzymes. The enzyme functions by catalyzing the hydrolysis of acetyl choline (neurotransmitter) into choline and acetic acid in the synapsis or neuro-muscular junctions in the tissues. The decreased levels of acetyl choline results in the progression of $\mathrm{AD}$. In the study, different concentrations of the plant extracts were tested for inhibition response of two cholinesterase enzymes i.e. Acetylcholinesterase (AChE) and butrylcholineterase (BChE) [88]. Interestingly, the inhibition response obtained for both esterases was dose dependent. $\mathrm{AP}_{\mathrm{E}}$ was most active at $400 \mu \mathrm{g} / \mathrm{mL}$ resulted in $81.5 \pm 1.6 \%$ inhibition of $\mathrm{AChE}$ and $83.9 \pm 1.4 \%$ for $\mathrm{BChE}$, followed by

Table 4 a-glucosidase and a-amylase inhibitory potential of different plant extracts

\begin{tabular}{|c|c|c|c|c|c|c|}
\hline \multirow[t]{3}{*}{ Enzymes } & \multirow[t]{3}{*}{ Sample } & \multicolumn{5}{|l|}{ Concentration } \\
\hline & & $25 \mu \mathrm{g} / \mathrm{mL}$ & $50 \mu \mathrm{g} / \mathrm{mL}$ & $100 \mu \mathrm{g} / \mathrm{mL}$ & $200 \mu \mathrm{g} / \mathrm{mL}$ & $400 \mu \mathrm{g} / \mathrm{mL}$ \\
\hline & & \multicolumn{5}{|l|}{$\%$ inhibition } \\
\hline \multirow[t]{5}{*}{ a-amylase } & $A P_{D W}$ & $17.83 \pm 0.19^{* *}$ & $26.22 \pm 0.34^{* *}$ & $29.05 \pm 0.33^{* *}$ & $32.03 \pm 0.66^{* *}$ & $37.43 \pm 0.65^{* *}$ \\
\hline & $\mathrm{AP}_{\mathrm{M}}$ & $13.39 \pm 0.17^{* * *}$ & $17.61 \pm 0.24^{* * *}$ & $17.93 \pm 0.31^{* * *}$ & $23.81 \pm 0.39^{* * *}$ & $29.31 \pm 0.48^{* * *}$ \\
\hline & $\mathrm{AP}_{\mathrm{E}}$ & $22.82 \pm 0.21^{*}$ & $31.08 \pm 0.28^{*}$ & $37.83 \pm 0.29^{*}$ & $51.26 \pm 0.82^{*}$ & $55.38 \pm 0.73^{*}$ \\
\hline & $\mathrm{AP}_{\mathrm{EA}}$ & $12.37 \pm 0.18^{* * *}$ & $17.92 \pm 0.19^{* * *}$ & $21.28 \pm 0.22^{* * *}$ & $22.71 \pm 0.30^{* * *}$ & $27.23 \pm 0.41^{* * *}$ \\
\hline & + control & $27.78 \pm 0.66$ & $44.87 \pm 0.93$ & $59.43 \pm 1.09$ & $73.20 \pm 1.51$ & $89.40 \pm 1.24$ \\
\hline \multirow[t]{5}{*}{ a-glucocidase } & $A P_{D W}$ & $14.94 \pm 0.21^{*}$ & $20.61 \pm 0.19^{*}$ & $22.91 \pm 0.19^{* *}$ & $30.51 \pm 0.44^{*}$ & $34.14 \pm 0.44^{* *}$ \\
\hline & $\mathrm{AP}_{\mathrm{M}}$ & $11.93 \pm 0.20^{* * *}$ & $16.72 \pm 0.17^{* *}$ & $20.17 \pm 0.15^{* *}$ & $20.52 \pm 0.29^{* *}$ & $24.63 \pm 0.32^{* * *}$ \\
\hline & $A P_{E}$ & $16.77 \pm 0.34^{*}$ & $22.82 \pm 0.21^{*}$ & $30.19 \pm 0.43^{*}$ & $33.61 \pm 0.31^{*}$ & $47.23 \pm 0.41^{*}$ \\
\hline & $A P_{E A}$ & $9.06 \pm 0.11^{* * *}$ & $14.98 \pm 0.18^{* *}$ & $16.28 \pm 0.21^{\text {*** }}$ & $20.75 \pm 0.27^{* *}$ & $23.71 \pm 0.31^{* * *}$ \\
\hline & + control & $27.32 \pm 0.73$ & $33.4 \pm 1.27$ & $53.45 \pm 1.11$ & $65.98 \pm 1.67$ & $84.34 \pm 1.92$ \\
\hline
\end{tabular}

Star *_*** represent; ${ }^{* * *}$ highly significant, ${ }^{* *}$ slightly significant and ${ }^{*}$ non-significant difference from the control at $P<0.05$ by one-way ANOVA in the column. Values are mean $\pm S D$ of triplicate. Where $A P_{D W}, A P_{M}, A P_{E}$ and $A P_{E A}$ stands for Distilled water, Methanol, Ethanol and Ethyl acetate extracts, respectively 
Table 5 Showing antioxidant potential of Aquilegia pubiflora extracts

\begin{tabular}{lllll}
\hline Concentration $\mathbf{2 0 0} \boldsymbol{\mu} \mathbf{g} / \mathbf{m L}$ & & & & \\
\hline Samples Extracts & TAC $(\boldsymbol{\mu g A A E} / \mathbf{m g})$ & TRP $(\boldsymbol{\mu g A A E} / \mathbf{m g})$ & ABTS (TEAC) & FRAP (\% FRSA) \\
\hline $\mathrm{AP}_{\mathrm{DW}}$ & $86.3 \pm 0.9$ & $86.3 \pm 2.1$ & $213.7 \pm 3.1$ & $221.4 \pm 1.38$ \\
$\mathrm{AP}_{\mathrm{M}}$ & $111.6 \pm 2.9$ & $76.7 \pm 0.9$ & $211.3 \pm 1.9$ & $198.6 \pm 1.2$ \\
$\mathrm{AP}_{\mathrm{E}}$ & $92.6 \pm 1.8$ & $89.2 \pm 2.4$ & $277.5 \pm 2.9$ & $289.9 \pm 1.74$ \\
$\mathrm{AP}_{\mathrm{EA}}$ & $97.4 \pm 1.3$ & $72.8 \pm 0.9$ & $188.5 \pm 2.2$ & $245.1 \pm 0.97$ \\
\hline
\end{tabular}

Values are mean $\pm \mathrm{SD}$ of triplicate. Where $A \mathrm{P}_{\mathrm{DW}}, \mathrm{AP}_{\mathrm{M}}, \mathrm{AP}_{\mathrm{E}}$ and $\mathrm{AP} \mathrm{PA}_{\mathrm{EA}}$ stands for Distilled water, Methanol, Ethanol and Ethyl acetate extracts, respectively

$\mathrm{AP}_{\mathrm{DW}}$ which resulted in $76.3 \pm 1.1 \%$ for $\mathrm{AChE}$ and $77.4 \pm 0.99 \%$ for $\mathrm{BChE}$, respectively. While lower inhibition response of $\mathrm{AChE} 27.6 \pm 0.31 \%$ and $\mathrm{BChE} 31.1 \pm$ $0.34 \%$ for $\mathrm{AP}_{\mathrm{EA}}$ was observed at $25 \mu \mathrm{g} / \mathrm{mL}$. Overall, all types of tested leaf extracts were found to be highly active against both the enzymes as indicated by their IC50 values for $\mathrm{AChE}$ and $\mathrm{BChE}$ in Table 6. Our results are matching with previous studies $[89,90]$.

\section{Anti-inflammatory assay}

The local vascularized or inflammatory reaction to toxins and irritants is known as inflammation. The antiinflammatory activity of Aquilegia pubiflora is focused on its conventional usages [34-37]. Phenylpropanoids are one of the essential groups of plant secondary metabolites which have potential to suppress main enzymes involved in the cycle of inflammation and hence, attributing anti-inflammatory properties to the plant extracts, [91]. Anti-inflammatory activity can be performed via different pathways, including inhibition of cyclooxygenases (COX-1 and COX-2), phospholipase A2 (sPLA2), and lipoxygenase (15-LOX, enzyme-generating eicosanoids), all results in reduction in level of leukotrienes and prostanoids [92]. Specific in vitro assays such as COX-2, COX-1, sPLA2, and 15-LOX were conducted to verify the anti-inflammatory function of the test samples. The highest anti-inflammatory activity among all samples was shown by $\mathrm{AP}_{\mathrm{E}}(52.5 \pm 1.1)$ against sPLA2, $(41.2 \pm 0.8)$ against 15 -LOX, followed by $(38.5 \pm 1.5)$ and
(32.4 \pm 0.8$)$ against COX-1 and COX-2, respectively. The percent inhibition of other tested samples is shown in the Fig. 3a. Previous studies have shown that the enhanced anti-inflammatory activity is due to the phenols and flavonoids content present in Aquilegia pubiflora [93]. The enhanced anti-inflammatory activity of some medicinal plants has been reported in previous studies [94]. The plant phytochemicals are solely responsible for inhibiting enzymes that cause body inflammation [95]

\section{Anti-aging assay}

This assay involved the screening of Aquilegia pubiflora plant extracts for their anti-aging potential. The test samples at a fixed concentration was used to evaluate their in vitro potency to inhibit enzymes such as tyrosinase, elastase, collagenase, hyaluronidase and AGEs (Fig. 3b). Collagenase, hyaluronidase and elastase like enzymes are responsible for the degradation of extracellular matrix components in the dermis. These enzymes cause skin alterations, which include deep wrinkles, skin tonus, and resilience losses [96-98]. Tyrosinase dysfunctions induce aging phenomenon and is the main causal agent of malignant melanoma and freckles or melissa like pigmentary disorders [99]. It has been reported that oxidative stress leads to provoke advanced glycation and produces (AGEs) end products which are directly associated with aging and age-related diseases [100, 101]. Such compounds, which have the potency to deter these enzymatic activities or pathways have been found to be attractive and efficient in

Table 6 AChE and BChE inhibitory potential of plant extracts

\begin{tabular}{|c|c|c|c|c|c|c|c|c|}
\hline \multirow[t]{2}{*}{ Enzymes } & \multirow[t]{2}{*}{ Sample } & \multirow[b]{2}{*}{$25 \mu \mathrm{g} / \mathrm{mL}$} & \multicolumn{6}{|l|}{ Concentration } \\
\hline & & & $50 \mu \mathrm{g} / \mathrm{mL}$ & $100 \mu \mathrm{g} / \mathrm{mL}$ & $200 \mu \mathrm{g} / \mathrm{mL}$ & $400 \mu \mathrm{g} / \mathrm{mL}$ & + control & IC50 \\
\hline \multirow[t]{4}{*}{ AChE } & $A P_{D W}$ & $31.7 \pm 0.70^{* * *}$ & $39.2 \pm 0.66^{* * *}$ & $47.5 \pm 0.80^{* * *}$ & $62.7 \pm 1.2^{*}$ & $76.3 \pm 1.1^{*}$ & $91.2 \pm 2.1$ & 193 \\
\hline & $\mathrm{AP}_{\mathrm{M}}$ & $34.2 \pm 0.81^{* * *}$ & $44.6 \pm 1.4^{* *}$ & $51.7 \pm 0.86^{*}$ & $59.1 \pm 0.92^{*}$ & $68.5 \pm 1.2^{*}$ & $87.1 \pm 2.2$ & 98 \\
\hline & $A P_{E}$ & $27.8 \pm 0.69^{* * *}$ & $34.9 \pm 0.61^{* *}$ & $57.4 \pm 0.92^{*}$ & $68.3 \pm 1.2^{*}$ & $81.5 \pm 1.6^{*}$ & $88.9 \pm 1.9$ & 91 \\
\hline & $A P_{E A}$ & $27.6 \pm 0.31^{* * *}$ & $38.7 \pm 0.50^{* *}$ & $45.3 \pm 0.73^{* *}$ & $57.4 \pm 0.81^{* *}$ & $71.3 \pm 0.81^{*}$ & $84.2 \pm 1.7$ & 163 \\
\hline \multirow[t]{4}{*}{ BChE } & $A P_{D W}$ & $34.7 \pm 0.93^{* * *}$ & $42.2 \pm 0.62^{* *}$ & $49.7 \pm 1.2^{* *}$ & $66 \pm 0.91^{*}$ & $77.4 \pm 0.99^{*}$ & $91.6 \pm 1.9$ & 154 \\
\hline & $\mathrm{AP}_{\mathrm{M}}$ & $31.9 \pm 0.60^{* * *}$ & $36.5 \pm 0.48^{* * *}$ & $42.7 \pm 0.72^{* *}$ & $61.1 \pm 0.79^{*}$ & $72.1 \pm 1.3^{*}$ & $90.3 \pm 1.9$ & 121 \\
\hline & $\mathrm{AP}_{\mathrm{E}}$ & $38.2 \pm 0.74 * * *$ & $41.9 \pm 0.59^{* *}$ & $54.2 \pm 1.4^{* *}$ & $71.4 \pm 0.93^{*}$ & $83.9 \pm 1.4^{*}$ & $92.1 \pm 1.8$ & 84 \\
\hline & $\mathrm{AP}_{\mathrm{EA}}$ & $31.1 \pm 0.34^{* *}$ & $43.1 \pm 0.75^{* *}$ & $57.3 \pm 0.88^{*}$ & $61.6 \pm 0.71^{*}$ & $67.1 \pm 0.73^{*}$ & $87.3 \pm 1.7$ & 95 \\
\hline
\end{tabular}

Star **** represent; ${ }^{* * *}$ highly significant, ${ }^{* *}$ slightly significant and ${ }^{*}$ non-significant difference from the control at $P<0.05$ by one-way ANOVA in the column. Values are mean $\pm S D$ of triplicate. Where $A P_{D W}, A P_{M}, A P_{E}$ and $A P_{E A}$ stands for Distilled water, Methanol, Ethanol and Ethyl acetate extracts, respectively 

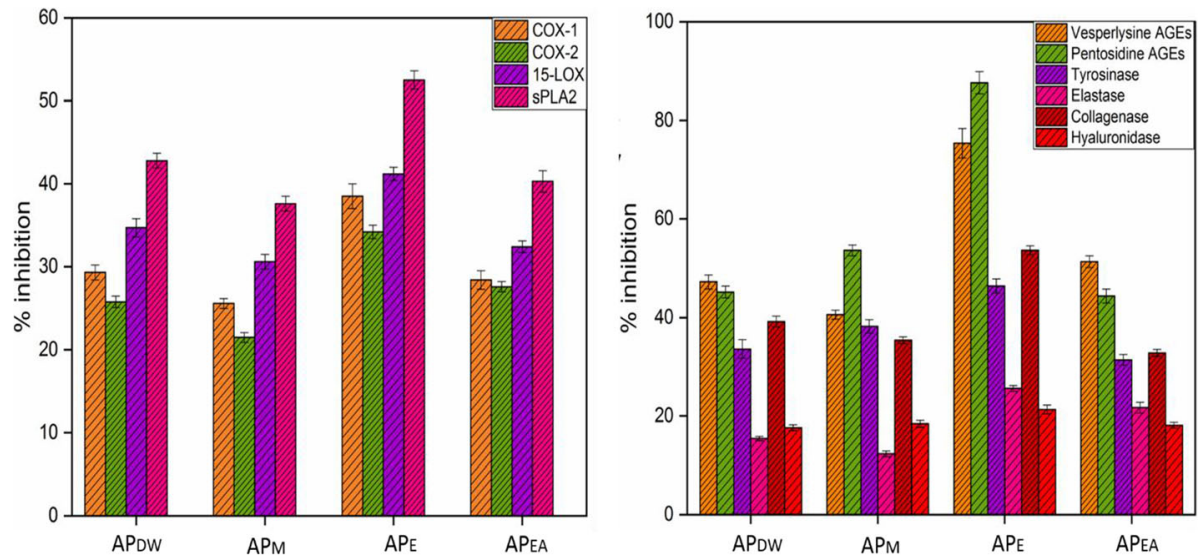

Fig. 3 a Anti-inflammatory potential of medicinally important Aquilegia pubiflora extracts, b Anti-aging potential of Aquilegia pubiflora leaf extracts. Values are mean $\pm \mathrm{SD}$ of triplicate. Where $\mathrm{AP}_{\mathrm{DW}}, \mathrm{AP}_{\mathrm{M}}, \mathrm{AP}_{\mathrm{E}}$ and $\mathrm{AP} \mathrm{P}_{\mathrm{EA}}$ stands for Distilled water, Methanol, Ethanol and Ethyl acetate extracts, respectively

cosmetics research. Several studies suggest that SIRT-1 (a class III deacetylase) and radical theory of aging have emerged as unique and potent agents for longevity and controlling oxidative stress effects. These agents mainly stimulate antioxidant response through FOXOs and p53 pathways [102, 103]. In our recent study, we have used Aquilegia pubiflora extracts, having important phytochemicals with anti-aging properties that can be exploited as anti-aging agents. We have detected strong inhibitory actions of $\mathrm{AP}_{\mathrm{E}}$ toward pentosidine AGEs (up to 87.6 \pm 2.26), followed by visperlysine AGEs (up to $75.4 \pm 2.99$ ) and (up to $53.6 \pm 0.9$ ) against collagenase. $\mathrm{AP}_{\mathrm{DW}}$ showed intermediate inhibitory effect toward pentosidine AGEs $(45.2 \pm 1.2)$ and tyrosinase $(33.6 \pm 1.9)$. Inhibitory effects observed for elastases were lowest marked up to $(25.6 \pm$ 0.6) for $\mathrm{AP}_{\mathrm{E}},(21.7 \pm 1.1)$ and $(15.4 \pm 0.4)$ for $\mathrm{AP}_{\mathrm{EA}}$ and $\mathrm{AP}_{\mathrm{DW}}$ respectively. From the above results, it has been elucidated that Aquilegia pubiflora has strong inhibitory potential against pentosidine and visperlysine AGEs.

\section{Anti-leishmanial activity}

Leishmaniasis, is highly neglected, non-contagious tropical and subtropical infectious disease caused by parasites largely found in Leishmania species. According to World Health Organization (WHO), the disease is endemic in 89 countries with annual global incidence of 1.5 to 2 million cases worldwide [104]. The disease is caused by an intracellular parasite and is transmitted to humans by sand flies (Phlebotomus and Lutzomyia) bite. Due to inappropriate vector and inefficient and unaffordable drugs the disease is at high risk of uncontrolled spreading. In our study, different types of Aquilegia pubiflora plant extracts ranging from 25 to $400 \mu \mathrm{g} / \mathrm{mL}$ were investigated against both promastigote and amastigote cultures of L. tropica via MTT assay as shown in Table 7.A dose-dependent cytotoxicity was observed with significant mortality rate of $52 \% \pm 1.2$ and $59 \% \pm 1.1$ for $\mathrm{AP}_{\mathrm{E}} 47 \% \pm 0.9$ and $51 \% \pm 0.9$ for $\mathrm{AP}_{\mathrm{M}}$ at $400 \mu \mathrm{g} / \mathrm{mL}$ for promastigote and amastigote form of the parasite, respectively. Moreover, significant $\mathrm{LC}_{50}$ was observed for both the patristic forms i.e., $376 \mu \mathrm{g} / \mathrm{mL}$ for promastigote and $344 \mu \mathrm{g} / \mathrm{mL}$ for amastigotes by $\mathrm{AP}_{\mathrm{E}}$ and $410 \mu \mathrm{g} / \mathrm{mL}$ for promastigote and $381 \mu \mathrm{g} / \mathrm{mL}$ for amastigote by $\mathrm{AP}_{\mathrm{M}}$.

\section{Anti-cancer activity against HepG2 cell line}

Recently, plant-derived compounds have been regarded as a powerful and helpful alternative source for treating hepatocellular carcinoma [105]. In our study, HPLC analysis confirmed the presence of vitexins, $p$-coumaric acid and ferulic acid, phenols and flavonoids, which are physiologically important against the treatment of pathogenic illness in humans and animals [106]. The chemo-preventive and less harmful nature of these compounds with effective anticancer potential provide a research hotspot for treatment of cancer. However, due to certain issues like inadequate solubility, structural deformation and bioavailability they target a cancer site very poorly [106, 107]. We explored the potential and cytotoxicity of Aquilegia pubiflora extracts against human hepatocytes (HepG2 cells) as shown in Fig. 4. Tested leaf extracts showed a significant inhibition of HepG2 cells by reducing their cell viability. Doxorubicin was used as positive control and resulted in $97.38 \pm 2.71 \%$ inhibition of HepG2 cells. On the other side the cytotoxicity or \% cell inhibition observed for aqueous plant extracts $\mathrm{AP}_{\mathrm{EA}}, \mathrm{AP}_{\mathrm{E}}$ and $\mathrm{AP}_{\mathrm{M}}$ was $50.08 \pm 2.4 \%, 42.68 \pm 2.1 \%$ and $45.68 \pm 2.1 \%$, while $\mathrm{AP}_{\mathrm{DW}}$ showed \% cell inhibition of $23.68 \pm 2.1 \%$, respectively. These results indicated that $\mathrm{AP}_{\mathrm{EA}}, \mathrm{AP}_{\mathrm{E}}$ and $\mathrm{AP}_{\mathrm{M}}$ extracts has successfully reduced the viability of HepG2 cells 
Table 7 Cytotoxic potential of Aquilegia pubiflora plant extracts against the promastigote and amastigote forms of Leishmania tropica (KWH23)

\begin{tabular}{|c|c|c|c|c|c|c|c|c|}
\hline \multirow[t]{2}{*}{ L. tropica } & \multirow[t]{2}{*}{ Sample } & \multirow[b]{2}{*}{$25 \mu \mathrm{g} / \mathrm{mL}$} & \multicolumn{6}{|l|}{ Concentration } \\
\hline & & & $50 \mu \mathrm{g} / \mathrm{mL}$ & $100 \mu \mathrm{g} / \mathrm{mL}$ & $200 \mu \mathrm{g} / \mathrm{mL}$ & $400 \mu \mathrm{g} / \mathrm{mL}$ & + control & IC50 \\
\hline \multirow[t]{4}{*}{ Promastigote } & $A P_{D W}$ & $16.7 \pm 0.40^{* * *}$ & $21.3 \pm 0.61^{* *}$ & $26.4 \pm 0.74^{* *}$ & $40.7 \pm 0.86^{*}$ & $44.1 \pm 1.1^{*}$ & $73.1 \pm 1.3$ & 443 \\
\hline & $\mathrm{AP}_{\mathrm{M}}$ & $14.2 \pm 0.51^{* * *}$ & $24.8 \pm 0.63^{* * *}$ & $31.6 \pm 0.70^{* *}$ & $41.3 \pm 0.91^{*}$ & $47 \pm 0.9^{*}$ & $78.8 \pm 1.7$ & 410 \\
\hline & $A P_{E}$ & $20 \pm 0.52^{* * *}$ & $24.5 \pm 0.56^{* * *}$ & $37.2 \pm 0.79^{* *}$ & $45.3 \pm 0.82^{*}$ & $52 \pm 1.2^{*}$ & $75.2 \pm 1.2$ & 376 \\
\hline & $A P_{E A}$ & $17.1 \pm 0.51^{* * *}$ & $28.1 \pm 0.50^{* *}$ & $35.8 \pm 0.81^{* *}$ & $40.4 \pm 0.73^{*}$ & $46.4 \pm 0.81^{*}$ & $75.4 \pm 1.1$ & 471 \\
\hline \multirow[t]{4}{*}{ Amastigote } & $A P_{D W}$ & $19.4 \pm 0.53^{* * *}$ & $32.8 \pm 0.97^{* *}$ & $28.9 \pm 0.72^{* * *}$ & $39.6 \pm 0.61^{*}$ & $47.4 \pm 0.82^{*}$ & $78.7 \pm 1.6$ & 464 \\
\hline & $\mathrm{AP}_{\mathrm{M}}$ & $19.9 \pm 0.63^{* * *}$ & $26.9 \pm 0.41^{* * *}$ & $32.5 \pm 0.86^{* *}$ & $41.1 \pm 0.69^{*}$ & $51 \pm 0.9^{*}$ & $78.1 \pm 1.6$ & 381 \\
\hline & $A P_{E}$ & $20.1 \pm 0.64^{* * *}$ & $31.1 \pm 0.69^{* * *}$ & $44.6 \pm 1.1^{* *}$ & $51.1 \pm 0.83^{*}$ & $59 \pm 1.1^{*}$ & $73.9 \pm 1.5$ & 344 \\
\hline & $A P_{E A}$ & $21.4 \pm 0.44^{* * *}$ & $33.8 \pm 0.55^{* *}$ & $37.8 \pm 0.78^{* *}$ & $42.3 \pm 0.78^{*}$ & $49.1 \pm 0.71^{*}$ & $74.9 \pm 1.1$ & 425 \\
\hline
\end{tabular}

Star **** represent; ${ }^{* * *}$ highly significant, ${ }^{* *}$ slightly significant and ${ }^{*}$ non-significant difference from control at $P<0.05$ by one-way ANOVA in the column. Values are mean $\pm S D$ of triplicate. Where $\mathrm{AP}_{\mathrm{DW}}, \mathrm{AP}_{\mathrm{M}}, \mathrm{AP}_{\mathrm{E}}$ and $\mathrm{AP}_{\mathrm{EA}}$ stands for Distilled water, Methanol, Ethanol and Ethyl acetate extracts, respectively

above $40 \%$, hence, exhibiting a good anti-cancer potential. The cytotoxic effects of these extracts may involve three key mechanisms, including their dissolution into functional entities, formation of reactive oxygen species (ROS) and DNA damage [108-110]. Moreover, physical properties, surface chemistry and dose dictates the overall uptake, elimination and anti-tumor properties of the test samples [110]. However, most of the available data about the in vitro anti-hepatocarcinoma activity are related to nature and presence of chemicals in plant extracts. Our findings thus augment and support the previously reported studies. The significant antitumor activity against HepG2 cell line may suggests an exciting potential of Aquilegia pubiflora and their extracts mediated oxide nanoparticles as promising anticancer agents.

\section{Discussion}

Himalayan Columbine (Aquilegia pubiflora Wall. Ex Royle) is a medicinal plant that has been used for decades to cure skin burns, jaundice, hepatitis, wound healing, cardiovascular and circulation problems [111]. The purpose of this study was to investigate the phytochemical constituents and further evaluate the antimicrobial, anti-parasitic, anti-Alzheimer, and cytotoxic properties of the Aquilegia pubiflora extracts $\left(\mathrm{AP}_{\mathrm{DW}}\right.$, $\mathrm{AP}_{\mathrm{M}}$, $\mathrm{APE}$, and $\left.\mathrm{AP}_{\mathrm{EA}}\right)$. Genus Aquilegia belongs to the Ranunculaceae family, which has more than 60 species of plants that are used primarily in South Asia and

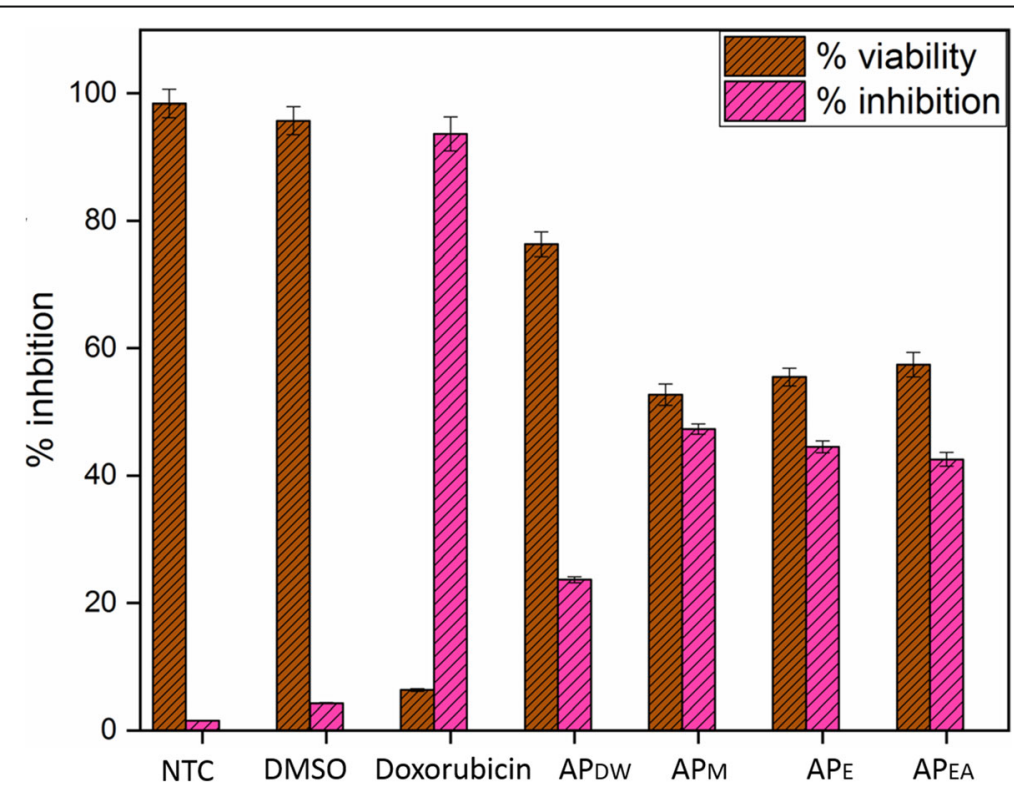

Fig. 4 Cytotoxic potential of the Aquilegia pubiflora leaf extracts against the HepG2 cell line. Values are mean \pm SD of triplicate. Doxorubicin was applied as positive control. Where $\mathrm{AP}_{\mathrm{DW}}, \mathrm{AP}_{\mathrm{M}}, \mathrm{AP}_{\mathrm{E}}, \mathrm{AP}_{\mathrm{EA}}$ and NTC stands for Distilled water, Methanol, Ethanol, Ethyl acetate extracts and NonTreated Cells, respectively 
worldwide for many medicinal purposes. These plants have abundant phytochemicals with efficient therapeutic properties [31-33]. Leaf extracts from Aquilegia publiflora were made using four different solvents with varied polarity. High-performance liquid chromatography (HPLC) was used to detect and quantify the particular phytochemicals contained in these extracts. HPLC results indicated a higher number of flavonoids and derivatives of hydroxycinnamic acid. Among the detected flavonoids orientin was observed to be present in a higher concentration for $\mathrm{AP}_{\mathrm{EA}}$ and $\mathrm{AP}_{\mathrm{E}}(171 \pm 2.4 \mu \mathrm{g} / \mathrm{g}$ DW and $983 \mu \mathrm{g} / \mathrm{g}$ DW respectively) while chlorogenic acid was found to be abundant hydroxycinnamic acid for both $\mathrm{AP}_{\mathrm{EA}}$ and $\mathrm{AP}_{\mathrm{E}}(1.15 \pm 0.08 \mu \mathrm{g} / \mathrm{g} \mathrm{DW}$ and $1.70 \mu \mathrm{g} / \mathrm{g}$ DW respectively). Our results are in accordance with previous reports $[67,111]$.

Antibiotic resistance is a severe problem that affects healthcare systems in both developing and developed countries across the world. The emergence and spread of multidrug-resistant diseases has had a significant impact on conventional antibiotic therapies [55]. As a result, in recent years, the search for novel sources of antimicrobial drugs has intensified in order to tackle resistant pathogenic diseases. Medicinal plants with antimicrobial potential have been extensively studied in this context, as they include a variety of bioactive chemicals with wellestablished therapeutic characteristics [56-58]. The research demonstrated that all plant extracts used had varied degrees of antimicrobial activity against all microorganisms tested at different concentrations. All the tested strains were susceptible to all extracts with $K$. pneumonia is found to be most susceptible. Inhibition zones measured at $5 \mathrm{mg} / \mathrm{mL}$ for $\mathrm{AP}_{\mathrm{DW}}, \mathrm{AP}_{\mathrm{M}}, \mathrm{AP}_{\mathrm{E}}$ and $\mathrm{AP}_{\mathrm{EA}}$ were $11.2 \pm 0.47,13.9 \pm 0.33,12.7 \pm 0.41$, and $13.5 \pm 0.62$ for Klebsiella pneumoniae, respectively. Our findings was close to that of previous studies that documented antibacterial activity of methanolic extract of $O$. corniculata [60]. The presence of antifungal toxicants in plant extracts may account for their antifungal effectiveness. Several authors have also observed fungicidal activity in a wide range of species. Antifungal chemicals are found in higher plants and are thought to be effective in avoiding plant infections [62]. Five pathogenic fungal strains (A. fumigatus, A. flavus, $M$. racemosus, $F$. solani and $A$. niger) were tested against Aquilegia pubiflora leaf extracts using the well diffusion method at concentrations in the range of $0.5 \mathrm{mg} /$ $\mathrm{mL}$ to $5 \mathrm{mg} / \mathrm{mL}$. The results clearly demonstrate that $A$. niger was the most susceptible strain in case of $\mathrm{AP}_{\mathrm{DW}}$ with the highest zone of inhibition $14.3 \pm 0.32,13.2 \pm 0.41$ in case of $\mathrm{AP}_{\mathrm{M}}, 13.7 \pm 0.39$ for $\mathrm{AP}_{\mathrm{E}}$ while $15.4 \pm 0.43$ zone of inhibition was recorded in case of $\mathrm{AP}_{\mathrm{EA}}$ at $5 \mathrm{mg} / \mathrm{mL}$, respectively. Previously, plant extracts from Ageratum conyzoides were found to have the same antifungal activity against the tested fungal specie $[63,112]$.
Plants have always long been an excellent source of medicines, with many medications commonly available are derived from them explicitly or indirectly. Different concentrations of the plant extracts were tested for inhibition response against $\alpha$ glucosidase, $\alpha$-amylase, acetylcholinesterase (AChE) and butrylcholineterase (BChE). Interestingly, the inhibition response obtained for both esterases was dose dependent. $\mathrm{AP}_{\mathrm{E}}$ was most active at $400 \mu \mathrm{g} / \mathrm{mL}$ resulted in $81.5 \pm 1.6 \%$ inhibition of $\mathrm{AChE}$ and $83.9 \pm 1.4 \%$ for $\mathrm{BChE}$, followed by $\mathrm{AP}_{\mathrm{DW}}$ which resulted in $76.3 \pm 1.1 \%$ for $\mathrm{AChE}$ and $77.4 \pm 0.99 \%$ for $\mathrm{BChE}$, respectively. While lower inhibition response of $\mathrm{AChE} 27.6 \pm 0.31 \%$ and $\mathrm{BChE} 31.1 \pm 0.34 \%$ for $\mathrm{AP}_{\mathrm{EA}}$ was observed at $25 \mu \mathrm{g} / \mathrm{mL}$. Overall, all types of tested leaf extracts were found to be highly active against both the enzymes as indicated by their IC50 values for $\mathrm{AChE}$ and $\mathrm{BChE}$. Our results are matching with previous studies $[89,90]$. In vitro cell-free $\alpha$-amylase and $\alpha$-glucosidase inhibition assays in a concentration range of 25 to $400 \mu \mathrm{g} / \mathrm{mL}$ were performed to study the anti-diabetic potential of Aquilegia pubiflora leaf extracts. $\mathrm{AP}_{\mathrm{E}}$ has a greater efficiency against $\alpha$-glucosidase $(47.23 \pm 0.41)$ and $\alpha$ amylase $(55.38 \pm 0.73)$ inhibition compared to $\mathrm{AP}_{\mathrm{DW}}$ ( $\alpha$-glucosidase: $34.14 \pm 0.44$ inhibition and $\alpha$-amylase: $37.43 \pm 0.65$ inhibition) and $\mathrm{AP}_{\mathrm{M}}$ ( $\alpha$-glucosidase: $24.63 \pm 0.32$ inhibition and $\alpha$-amylase: $29.31 \pm 0.48$ inhibition). Our results are in harmony with previous reports [78, 79].

In our recent study, we have used Aquilegia pubiflora extracts, having important phytochemicals with antiinflammatory and anti-aging properties that can be exploited for the production of cosmetics. Antiinflammatory activity was performed via different pathways, including inhibition of cyclooxygenases (COX-1 and COX-2), phospholipase A2 (sPLA2), and lipoxygenase (15-LOX, enzyme-generating eicosanoids), all results in reduction in level of leukotrienes and prostanoids [92]. Specific in vitro assays such as COX-2, COX-1, sPLA2, and 15-LOX were conducted to verify the antiinflammatory function of the test samples. The highest anti-inflammatory activity among all samples was shown by $\mathrm{AP}_{\mathrm{E}}(52.5 \pm 1.1)$ against sPLA2, $(41.2 \pm 0.8)$ against 15-LOX, followed by $(38.5 \pm 1.5)$ and $(32.4 \pm 0.8)$ against COX-1 and COX-2, respectively. Previous studies have shown that the enhanced anti-inflammatory activity is due to the phenols and flavonoids content present in Aquilegia pubiflora [93]. We have detected strong inhibitory actions of $\mathrm{AP}_{\mathrm{E}}$ toward pentosidine AGEs (up to 87.6 \pm 2.26 ), followed by visperlysine AGEs (up to $75.4 \pm$ 2.99 ) and (up to $53.6 \pm 0.9$ ) against collagenase. $\mathrm{AP}_{\mathrm{DW}}$ showed intermediate inhibitory effect toward pentosidine AGEs $(45.2 \pm 1.2)$ and tyrosinase $(33.6 \pm 1.9)$. 
Inhibitory effects observed for elastases were lowest marked up to $(25.6 \pm 0.6)$ for $\mathrm{AP}_{\mathrm{E}},(21.7 \pm 1.1)$ and $(15.4 \pm 0.4)$ for $\mathrm{AP}_{\mathrm{EA}}$ and $\mathrm{AP}_{\mathrm{DW}}$ respectively. From the above results, it has been elucidated that Aquilegia pubiflora has strong inhibitory potential against pentosidine and visperlysine AGEs.

Protein kinase enzymes phosphorylate serinethreonine and tyrosine amino acid residues that have a key function in cellular proliferation, differentiation and apoptosis [68]. Deregulated phosphorylation by protein kinase can lead to tumor growth and entities with capability to inhibit these enzymes, are important area in anticancer research [69]. Streptomyces $85 \mathrm{E}$ strain was used to check the protein kinase inhibition potential of Aquilegia pubiflora extracts. Comparatively, $\mathrm{AP}_{\mathrm{E}}$ showed the largest bald zone $14.6 \pm 0.69$ than $\mathrm{AP}_{\mathrm{M}}$ $14.1 \pm 0.35, \mathrm{AP}_{\mathrm{DW}} 13.8 \pm 0.31$ and $\mathrm{AP}_{\mathrm{EA}} 13.2 \pm 0.29$ at 5 $\mathrm{mg} / \mathrm{mL}$. Lowest $5.3 \pm 0.21$ zone appeared in case of $\mathrm{AP}_{\mathrm{DW}} 0.5 \mathrm{mg} / \mathrm{mL}$ representing least potential against Streptomyces hyphae growth. All the tested plant extracts inhibited Streptomyces strain at concentrationdependent manner as indicated in Fig. 2a. Overall, results showed that the entire test samples acquire vital metabolites responsible for anti-cancerous potentials in Aquilegia pubiflora. Our results are strongly supported by a previous report, which was conducted on the evaluation of hyphae formation inhibition in Streptomyces $85 \mathrm{E}$. After preliminary evaluation of test extracts against protein kinase enzyme we explored the inhibition potential of Aquilegia pubiflora extracts against human hepatocytes (HepG2 cells). Tested leaf extracts showed a significant inhibition of HepG2 cells by reducing their cell viability. Doxorubicin was used as positive control and resulted in $97.38 \pm 2.71 \%$ inhibition of HepG2 cells. On the other side the cytotoxicity or \% cell inhibition observed for aqueous plant extracts $\mathrm{AP}_{\mathrm{EA}}, \mathrm{AP}_{\mathrm{E}}$ and $\mathrm{AP}_{\mathrm{M}}$ was $50.08 \pm 2.4 \%, 42.68 \pm 2.1 \%$ and $45.68 \pm 2.1 \%$, while $\mathrm{AP}_{\mathrm{DW}}$ showed \% cell inhibition of $23.68 \pm 2.1 \%$, respectively. These results indicated that $A P_{E A}, A_{E}$ and $A_{P}$ extracts has successfully reduced the viability of HepG2 cells above $40 \%$, hence, exhibiting a good anti-cancer potential. The cytotoxic effects of these extracts may involve three key mechanisms, including their dissolution into functional entities, formation of reactive oxygen species (ROS) and DNA damage [108-110].

\section{Conclusion}

The study findings indicated that the solvent form and polarity have an impact on extraction effectiveness, biological performance, and the quality of the pharmacological reaction. If a multi range polarity based solvent method is used in the preliminary screening stages, followed by extract optimization and bioactivity guided isolation of potentially active compounds, better results can be obtained. Different plant extracts tested have demonstrated excellent antibacterial and antifungal activities, especially against $K$. pneumonia and $A$. niger. Similarly, both amastigote and promastigote variants of the parasite Leishmania tropica were found to be particularly susceptible to test samples. We discovered that these plant extracts can be used to treat hepatocarcinoma because they showed significant cytotoxicity against HepG2 cells. Furthermore, substantial inhibition activity against $\alpha$-amylase, $\alpha$-glucosidase, Acetylcholinesterase (AChE), and Butrylcholinesterase (BChE) was observed, paying the way for its use as anti-diabetic and anti-Alzheimer's therapeutics. Pentosidine-Like AGEs were shown to have a high benefit and antiinflammatory capacity. The findings from the abovementioned biological activities suggested that Aquilegia pubiflora leaf extract could be a suitable candidate for various biomedical applications.

\section{Abbreviations}

TAC: Total antioxidant capacity; AD: Alzheimer's disease; TRP: Total reducing power; FRSA: Free radical scavenging assay; AChE: Acetylcholinesterase; BChE: Butyrylcholinesterase; DMSO: Dimethyl sulfoxide

\section{Acknowledgments \\ We are thankful to Department of Biotechnology, Quaid-i-Azam University, Islamabad, Pakistan for their support.}

\section{Authors' contributions}

$\mathrm{HJ}$ conceptualized, designed and performed the experiments. HJ wrote the manuscript. HU, MS and GZ provide reagents, analytical tools and software analysis. SM and SD helped in experiments. $\mathrm{CH}$ and BHA supervised the research work. All authors read and approved the manuscript.

\section{Funding}

No fund was taken from any source.

\section{Availability of data and materials}

The datasets used and analyzed during the current research work are available from the corresponding author on reasonable request.

\section{Declarations}

Ethics approval and consent to participate

Ethical committee approval has been provided as supplementary material.

\section{Consent for publication}

The authors of the current work gave consent for publication to Mr. Hasnain Jan.

Competing interests

All authors declare no competing interests.

\section{Author details}

'Department of Biotechnology, Quaid-i-Azam University, Islamabad 45320, Pakistan. '2Laboratoire de Biologie des Ligneux et des Grandes Cultures (LBLGC EA1207), INRA USC1328, Plant Lignans Team, Université d'Orléans, Pôle Universitaire d'Eure et Loir, 21 rue de Loigny la Bataille, 28000 Chartres, France. ${ }^{3}$ Bioactifs et Cosmétiques, GDR 3711 COSMACTIFS, CNRS/Université d’Orléans, 45067 Orléans, CÉDEX 2, France. 


\section{Received: 11 October 2020 Accepted: 24 May 2021} Published online: 07 June 2021

\section{References}

1. Tripathi I, Mahendra K, Pardhi Yogesh DA, Dwivedi Noopa KA. Gupta Priyanka. HPLC analysis of methanolic extract of some medicinal plant leaves of Myrtaceae family. Int Pharm Sci. 2012;2(3):49-53.

2. Chew YL, Chan EWL, Tan PL, Lim YY, Stanslas J, Goh JK. Assessment of phytochemical content, polyphenolic composition, antioxidant and antibacterial activities of Leguminosae medicinal plants in peninsular Malaysia. BMC Complement Altern Med. 2011;11(1):12. https://doi.org/10.11 86/1472-6882-11-12

3. Mukherjee PK, Venkatesh P, Ponnusankar S. Ethnopharmacology and integrative medicine-let the history tell the future. J Ayurveda Integ Med. 2010;1(2):100-9. https://doi.org/10.4103/0975-9476.65077.

4. Sen A, Batra A. Evaluation of antimicrobial activity of different solvent extracts of medicinal plant: Melia azedarach L. Int J Curr Pharm Res. 2012; 4(2):67-73.

5. Haraguchi H, Kataoka S, Okamoto S, Hanafi M, Shibata K. Antimicrobial triterpenes from llex integra and the mechanism of antifungal action. Phytother Res. 1999;13(2):151-6. https://doi.org/10.1002/(SICI)1099-1573 (199903)13:2<151\%:AID-PTR391>3.0.CO;2-C

6. Hudaib M, Mohammad M, Bustanji Y, Tayyem R, Yousef M, Abuirjeie M, et al. Ethnopharmacological survey of medicinal plants in Jordan, Mujib nature reserve and surrounding area. J Ethnopharmacol. 2008;120(1):63-71. https:// doi.org/10.1016/j.jep.2008.07.031.

7. Jänicke RU, Sprengart ML, Wati MR, Porter AG. Caspase-3 is required for DNA fragmentation and morphological changes associated with apoptosis. J Biol Chem. 1998;273(16):9357-60. https://doi.org/10.1074/jbc.273.16.9357.

8. Conforti F, loele G, Statti G, Marrelli M, Ragno G, Menichini F. Antiproliferative activity against human tumor cell lines and toxicity test on Mediterranean dietary plants. Food Chem Toxicol. 2008;46(10):3325-32. https://doi.org/10.1016/j.fct.2008.08.004.

9. Chander M. Anticancer efficacy of some plant Phenolics-a recent scenario. Int J Curr Microbiol App Sci. 2018;7(10):1746-68. https://doi.org/10.20546/ ijcmas.2018.710.200.

10. Zhang H, Tsao R. Dietary polyphenols, oxidative stress and antioxidant and anti-inflammatory effects. Curr Opin Food Sci. 2016;8:33-42. https://doi.org/1 0.1016/j.cofs.2016.02.002

11. Gohain A, Sarma RK, Debnath R, Saikia J, Singh BP, Sarmah R, et al. Phylogenetic affiliation and antimicrobial effects of endophytic actinobacteria associated with medicinal plants: prevalence of polyketide synthase type II in antimicrobial strains. Folia Microbiol. 2019;64(4):481-96. https://doi.org/10.1007/s12223-018-00673-0.

12. Orhan IE, Özçelik B, Kartal M, Kan Y. Antimicrobial and antiviral effects of essential oils from selected Umbelliferae and Labiatae plants and individual essential oil components. Turk J Biol. 2012;36(3):239-46.

13. Pozdnyakov DI, Pozdnyakova AE, Adzhiahmetova SL, Chervonnaya NM, Zolotych DS, Lyakhova NS, et al. Antihypoxic and anti-ischemic properties of the North Caucasus flora plant extracts. Bol Latinoam Caribe Plantas Med Aromát. 2019;18(5):504-17. https://doi.org/10.35588/blacpma.19.18.5.33.

14. Luna-Vázquez FJ, Ibarra-Alvarado C, Camacho-Corona MDR, Rojas-Molina A, Rojas-Molina JI, García A, et al. Vasodilator activity of compounds isolated from plants used in Mexican traditional medicine. Molecules. 2018;23(6): 1474. https://doi.org/10.3390/molecules23061474.

15. Kähkönen MP, Hopia Al, Vuorela HJ, Rauha J-P, Pihlaja K, Kujala TS, et al. Antioxidant activity of plant extracts containing phenolic compounds. J Agric Food Chem. 1999;47(10):3954-62. https://doi.org/10.1021/jf9901461.

16. Boligon AA, Pereira RP, Feltrin AC, Machado MM, Janovik V, Rocha JBT, et al. Antioxidant activities of flavonol derivatives from the leaves and stem bark of Scutia buxifolia Reiss. Bioresour Technol. 2009;100(24):6592-8. https://doi. org/10.1016/j.biortech.2009.03.091.

17. Su X-Y, Wang Z-Y, Liu J-R. In vitro and in vivo antioxidant activity of Pinus koraiensis seed extract containing phenolic compounds. Food Chem. 2009; 117(4):681-6. https://doi.org/10.1016/j.foodchem.2009.04.076.

18. Kintzios S, Papageorgiou K, Yiakoumettis I, Baričevič D, Kušar A. Evaluation of the antioxidants activities of four Slovene medicinal plant species by traditional and novel biosensory assays. J Pharm Biomed Anal. 2010;53(3): 773-6. https://doi.org/10.1016/j.jpba.2010.05.013.
19. Sparg S, Light M, Van Staden J. Biological activities and distribution of plant saponins. J Ethnopharmacol. 2004;94(2-3):219-43. https://doi.org/10.1016/j. jep.2004.05.016

20. Kumar S, Bajwa B, Kuldeep S, Kalia A. Anti-inflammatory activity of herbal plants: a review. Int J Adv Pharm Biol Chem. 2013;2(2):272-81.

21. Chi $Y$, Jong H, Son $K$, Chang H, Kang S, Kim H. Effects of naturally occurring prenylated flavonoids on arachidonic acid metabolizing enzymes: Cylooxygenases and lipoxygenases. Biochem Pharmacol. 2001;62(9):1185-91. https://doi.org/10.1016/S0006-2952(01)00773-0.

22. Jang DS, Cuendet M, Hawthorne ME, Kardono LB, Kawanishi K, Fong HH, et al. Prenylated flavonoids of the leaves of Macaranga conifera with inhibitory activity against cyclooxygenase-2. Phytochemistry. 2002;61(7):86772. https://doi.org/10.1016/S0031-9422(02)00378-3.

23. Ho Y-S, So K-F, Chang RC-C. Anti-aging herbal medicine-how and why can they be used in aging-associated neurodegenerative diseases? Ageing Res Rev. 2010;9(3):354-62. https://doi.org/10.1016/j.arr.2009.10.001.

24. Frawley D, Ranade S. Ayurveda, nature's medicine: Motilal Banarsidass Publ; 2004.

25. Ekor M. The growing use of herbal medicines: issues relating to adverse reactions and challenges in monitoring safety. Front Pharmacol. 2014:4:177.

26. Shoeb M, Celik S, Jaspars M, Kumarasamy Y, MacManus SM, Nahar L, et al. Isolation, structure elucidation and bioactivity of schischkiniin, a unique indole alkaloid from the seeds of Centaurea schischkinii. Tetrahedron. 2005: 61(38):9001-6. https://doi.org/10.1016/j.tet.2005.07.047.

27. Khan T, Abbasi BH, Khan MA, Azeem M. Production of biomass and useful compounds through elicitation in adventitious root cultures of Fagonia indica. Ind Crop Prod. 2017;108:451-7. https://doi.org/10.1016/j.indcrop.2017. 07.019 .

28. Abbasi BH, Zahir A, Ahmad W, Nadeem M, Giglioli-Guivarc'h N, Hano C. Biogenic zinc oxide nanoparticles-enhanced biosynthesis of lignans and neolignans in cell suspension cultures of Linum usitatissimum L. Artif Cells Nanomed Biotechnol. 2019:47(1):1367-73. https://doi.org/10.1080/216914 01.2019 .1596942$.

29. Kainsa S, Kumar P, Rani P. Medicinal plants of Asian origin having anticancer potential: short review. Asian J Biomed Pharm Sci. 2012;2(10):1-11.

30. Kaur R, Kapoor K, Kaur H. Plants as a source of anticancer agents. J Nat Prod Plant Resour. 2011;1(1):119-24.

31. Yu Y, Yi Z-b, Liang Y-Z. Validate antibacterial mode and find main bioactive components of traditional Chinese medicine Aquilegia oxysepala. Bioorg Med Chem Lett. 2007:17(7):1855-9. https://doi.org/10.1016/j.bmcl.2007.01.032.

32. Mushtaq S, Aga MA, Qazi PH, Ali MN, Shah AM, Lone SA, et al. Isolation, characterization and HPLC quantification of compounds from Aquilegia fragrans Benth: their in vitro antibacterial activities against bovine mastitis pathogens. J Ethnopharmacol. 2016;178:9-12. https://doi.org/10.1016/j.jep.2 015.11.039.

33. Bylka W, Frański R, Stobiecki M. Differentiation between isomeric acacetin-6C-(6 "-O-malonyl) glucoside and acacetin-8-C-(6 "-O-malonyl) glucoside by using low-energy CID mass spectra. J Mass Spectrom. 2002;37(6):648-50. https://doi.org/10.1002/jms.313.

34. Thatoi P, Kerry RG, Gouda S, Das G, Pramanik K, Thatoi H, et al. Photomediated green synthesis of silver and zinc oxide nanoparticles using aqueous extracts of two mangrove plant species, Heritiera fomes and Sonneratia apetala and investigation of their biomedical applications. J Photochem Photobiol B Biol. 2016;163:311-8. https://doi.org/10.1016/j. jphotobiol.2016.07.029.

35. Ahmed MJ, Murtaza G. A study of medicinal plants used as ethnoveterinary: harnessing potential phytotherapy in Bheri, district Muzaffarabad (Pakistan). J Ethnopharmacol. 2015;159:209-14. https://doi.org/10.1016/j.jep.2014.11.016

36. Hussain I, Bano A, Ullah F. Traditional drug therapies from various medicinal plants of central karakoram national park, Gilgit-Baltistan Pakistan. Pak J Bot. 2011:43:79-84.

37. Adnan M, Begum S, Khan AL, Tareen AM, Lee I-J. Medicinal plants and their uses in selected temperate zones of Pakistani Hindukush-Himalaya. J Med Plant Res. 2012:6(24):4113-27.

38. Ahmad W, Zahir A, Nadeem M, Zia M, Hano C, Abbasi BH. Thidiazuroninduced efficient biosynthesis of phenolic compounds in callus culture of Ipomoea turbinata Lagasca and Segura. In Vitro Cell Dev Biol Plant. 2019; 55(6):710-9. https://doi.org/10.1007/s11627-019-10027-1.

39. Shah M, Nawaz S, Jan H, Uddin N, Ali A, Anjum S, et al. Synthesis of biomediated silver nanoparticles from Silybum marianum and their biological and clinical activities. Mater Sci Eng C. 2020;(112)110889. 
40. Ahmed S, Ahmad M, Swami BL, Ikram S. A review on plants extract mediated synthesis of silver nanoparticles for antimicrobial applications: a green expertise. J Adv Res. 2016;7(1):17-28. https://doi.org/10.1016/j.jare.201 5.02.007.

41. Zohra T, Ovais M, Khalil AT, Qasim M, Ayaz M, Shinwari ZK. Extraction optimization, total phenolic, flavonoid contents, HPLC-DAD analysis and diverse pharmacological evaluations of Dysphania ambrosioides (L.) Mosyakin \& Clemants. Nat Prod Res. 2019;33(1):136-42. https://doi.org/10.1 080/14786419.2018.1437428.

42. Saratale RG, Shin HS, Kumar G, Benelli G, Kim D-S, Saratale GD. Exploiting antidiabetic activity of silver nanoparticles synthesized using Punica granatum leaves and anticancer potential against human liver cancer cells (HepG2). Artif Cells Nanomed Biotechnol. 2018:46(1):211-22. https://doi. org/10.1080/21691401.2017.1337031.

43. Usman $\mathrm{H}$, Ullah MA, Jan $\mathrm{H}$, Siddiquah A, Drouet $\mathrm{S}$, Anjum $\mathrm{S}$, et al. Interactive effects of wide-Spectrum monochromatic lights on phytochemical production, antioxidant and biological activities of Solanum xanthocarpum callus cultures. Molecules. 2020;25(9):2201. https://doi.org/10.3390/ molecules25092201.

44. Ahmed M, Adil M, Haq I-u, Tipu MK, Qasim M, Gul B. RP-HPLC-based phytochemical analysis and diverse pharmacological evaluation of Quercus floribunda Lindl. ex A. Camus nuts extracts. Nat Prod Res. 2019:1-6. https:// doi.org/10.1080/14786419.2019.1667347.

45. Shah M, Jan H, Drouet S, Tungmunnithum D, Shirazi JH, Hano C, et al. Chitosan Elicitation Impacts Flavonolignan Biosynthesis in Silybum marianum (L.) Gaertn Cell Suspension and Enhances Antioxidant and AntiInflammatory Activities of Cell Extracts. Molecules. 2021;26(4):791.

46. Nazir S, Jan H, Tungmunnithum D, Drouet S, Zia M, Hano C, et al. Callus culture of Thai basil is an effective biological system for the production of antioxidants. Molecules. 2020;25(20):4859. https://doi.org/10.3390/ molecules25204859.

47. Imran M, Jan H, Faisal S, Shah SA, Shah S, Khan MN, et al. In vitro examination of anti-parasitic, Anti-Alzheimer, Insecticidal and Cytotoxic Potential of Ajuga Bracteosa Wallich Leaves Extracts. Saudi J Biol Sci. 2021; 28(5):3031-3036

48. Kaewseejan N, Siriamornpun S. Bioactive components and properties of ethanolic extract and its fractions from Gynura procumbens leaves. Ind Crop Prod. 2015;74:271-8. https://doi.org/10.1016/j.indcrop.2015.05.019.

49. Chai W-M, Huang Q, Lin M-Z, Ou-Yang C, Huang W-Y, Wang Y-X, et al Condensed tannins from longan bark as inhibitor of tyrosinase: structure, activity, and mechanism. J Agric Food Chem. 2018;66(4):908-17. https://doi. org/10.1021/acs.jafc.7b05481.

50. Wittenauer J, Mäckle S, Sußmann D, Schweiggert-Weisz U, Carle R. Inhibitory effects of polyphenols from grape pomace extract on collagenase and elastase activity. Fitoterapia. 2015;101:179-87. https://doi.org/10.1016/j. fitote.2015.01.005.

51. Kolakul P, Sripanidkulchai B. Phytochemicals and anti-aging potentials of the extracts from Lagerstroemia speciosa and Lagerstroemia floribunda. Ind Crop Prod. 2017;109:707-16. https://doi.org/10.1016/j.indcrop.2017.09.026.

52. Ahmad A, Syed F, Shah A, Khan Z, Tahir K, Khan AU, et al. Silver and gold nanoparticles from Sargentodoxa cuneata: synthesis, characterization and antileishmanial activity. RSC Adv. 2015;5(90):73793-806. https://doi.org/10.1 039/C5RA13206A.

53. Santos-Sánchez NF, Salas-Coronado R, Hernández-Carlos B, VillanuevaCañongo C. Shikimic acid pathway in biosynthesis of phenolic compounds. In: Plant Physiological Aspects of Phenolic Compounds: IntechOpen; 2019.

54. Naveed M, Hejazi V, Abbas M, Kamboh AA, Khan GJ, Shumzaid M, et al. Chlorogenic acid (CGA): a pharmacological review and call for further research. Biomed Pharmacother. 2018;97:67-74. https://doi.org/10.1016/j. biopha.2017.10.064

55. Drlica KS, Perlin DS. Antibiotic resistance: understanding and responding to an emerging crisis, Portable Documents: FT Press; 2010.

56. Romero CD, Chopin SF, Buck G, Martinez E, Garcia M, Bixby L. Antibacterial properties of common herbal remedies of the southwest. J Ethnopharmacol. 2005;99(2):253-7. https://doi.org/10.1016/j.jep.2005.02.028.

57. Boucher HW, Talbot GH, Bradley JS, Edwards JE, Gilbert D, Rice LB, et al. Bad bugs, no drugs: no ESKAPE! An update from the Infectious Diseases Society of America. Clin Infect Dis. 2009;48(1):1-12. https://doi. org/10.1086/595011.

58. Talbot GH, Bradley J, Edwards JE Jr, Gilbert D, Scheld M, Bartlett JG. Bad bugs need drugs: an update on the development pipeline from the antimicrobial availability task force of the Infectious Diseases Society of America. Clin Infect Dis. 2006:42(5):657-68. https://doi.org/10.1086/499819.

59. Mohseni M, Norouzi H, Hamedi J, Roohi A. Screening of antibacterial producing actinomycetes from sediments of the Caspian Sea. Int J Mol Cell Med. 2013;2(2):64-71.

60. Raghavendra M, Satish S, Raveesha K. Phytochemical analysis and antibacterial activity of Oxalis corniculata; a known medicinal plant. My Science. 2006;1(1):72-8.

61. Manandhar S, Luitel S, Dahal RK. In vitro antimicrobial activity of some medicinal plants against human pathogenic bacteria. J Trop Med. 2019; 2019:1-5. https://doi.org/10.1155/2019/1895340.

62. Cherkupally $\mathrm{R}$, Kota SR, Amballa $H$, Reddy BN. In vitro antifungal potential of plant extracts against Fusarium oxysporum, Rhizoctonia solani and Macrophomina phaseolina. Ann Plant Sci. 2017;6(9):1676-80. https://doi. org/10.21746/aps.2017.9.2.

63. Wuyep PA, Musa HD, Ezemokwe GC, Nyam DD, MD SG. Phytochemicals from Ageratum conyzoides L. Extracts and their Antifungal Activity against Virulent Aspergillus spp; 2017.

64. Kareem FH, Matloob AA. Efficiency of some biological control agents and plant extracts against FUSARIUM SOLANI causing agent of damping off disease on tomato. Plant Arch. 2019;19(2):937-42.

65. Patterson H, Nibbs R, Mclnnes I, Siebert S. Protein kinase inhibitors in the treatment of inflammatory and autoimmune diseases. Clin Exp Immunol. 2014;176(1):1-10. https://doi.org/10.1111/cei.12248.

66. Ferguson FM, Gray NS. Kinase inhibitors: the road ahead. Nat Rev Drug Discov. 2018;17(5):353-77. https://doi.org/10.1038/nrd.2018.21.

67. Jan H, Shah M, Usman H, Khan A, Muhammad Z, Hano C, et al. Biogenic synthesis and characterization of antimicrobial and anti-parasitic zinc oxide $(\mathrm{ZnO})$ nanoparticles using aqueous extracts of the Himalayan columbine (Aquilegia pubiflora). Front Mater. 2020;7:249. https://doi.org/10.3389/fmats.2 020.00249 .

68. Roskoski R Jr. RAF protein-serine/threonine kinases: structure and regulation. Biochem Biophys Res Commun. 2010;399(3):313-7. https://doi.org/10.1016/j. bbrc.2010.07.092.

69. Isakov N. Protein kinase C (PKC) isoforms in cancer, tumor promotion and tumor suppression. In: Seminars in cancer biology: Elsevier; 2018. p. 36-52.

70. Yao G, Sebisubi FM, Voo LYC, Ho CC, Tan GT, Chang LC. Citrinin derivatives from the soil filamentous fungus Penicillium sp. H9318. J Braz Chem Soc. 2011;22(6):1125-9. https://doi.org/10.1590/S0103-50532011000600018.

71. Halim M, Halim A. The effects of inflammation, aging and oxidative stress on the pathogenesis of diabetes mellitus (type 2 diabetes). Diabetes Metab Synd. 2019;13(2):1165-72. https://doi.org/10.1016/j.dsx.2019.01.040.

72. Olokoba AB, Obateru OA, Olokoba LB. Type 2 diabetes mellitus: a review of current trends. Oman Med J. 2012;27(4):269-73. https://doi.org/10.5001/ omj.2012.68.

73. Hano C, Renouard S, Molinié R, Corbin C, Barakzoy E, Doussot J, et al. Flaxseed (Linum usitatissimum L.) extract as well as (+)-secoisolariciresinol diglucoside and its mammalian derivatives are potent inhibitors of aamylase activity. Bioorg Med Chem Lett. 2013;23(10):3007-12. https://doi. org/10.1016/j.bmcl.2013.03.029.

74. Salehi B, Kumar NVA, Şener B, Sharifi-Rad M, Klıç M, Mahady GB, et al. Medicinal plants used in the treatment of human immunodeficiency virus. Int J Mol Sci. 2018:19(5):1459. https://doi.org/10.3390/ijms19051459.

75. Salehi B, Ata A, Anil Kumar NV, Sharopov F, Ramírez-Alarcón K, Ruiz-Ortega A, et al. Antidiabetic potential of medicinal plants and their active components. Biomolecules. 2019;9(10):551. https://doi.org/10.3390/biom9100551.

76. Mishra AP, Sharifi-Rad M, Shariati MA, Mabkhot YN, Al-Showiman SS, Rauf A et al. Bioactive compounds and health benefits of edible Rumex species-a review. Cell Mol Biol. 2018;64(8):27-34. https://doi.org/10.14715/cmb/2018. 64.8 .5 .

77. Abdolshahi A, Naybandi-Atashi S, Heydari-Majd M, Salehi B, Kobarfard F, Ayatollahi SA, et al. Antibacterial activity of some Lamiaceae species against Staphylococcus aureus in yoghurt-based drink (Doogh). Cell Mol Biol. 2018; 64(8):71-7. https://doi.org/10.14715/cmb/2018.64.8.11.

78. Obafemi T, Akinmoladun A, Olaleye M, Agboade SO, Onasanya AA. Antidiabetic potential of methanolic and flavonoid-rich leaf extracts of Synsepalum dulcificum in type 2 diabetic rats. J Ayurveda Integ Med. 2017; 8(4):238-46. https://doi.org/10.1016/j.jaim.2017.01.008.

79. Zengin G, Locatelli M, Carradori S, Mocan AM, Aktumsek A. Total phenolics, flavonoids, condensed tannins content of eight Centaurea species and their broad inhibitory activities against cholinesterase, tyrosinase, a-amylase and 
a-glucosidase. Notulae Botan Horti Agrobotan Cluj-Napoca. 2016;44(1):195200. https://doi.org/10.15835/nbha44110259.

80. Sergiev I, Todorova D, Shopova E, Jankauskiene J, Jankovska-Bortkevič E, Jurkoniené S. Exogenous auxin type compounds amend PEG-induced physiological responses of pea plants. Sci Hortic. 2019;248:200-5. https://doi. org/10.1016/.scienta.2019.01.015.

81. Mohamed HI, Akladious SA. Changes in antioxidants potential, secondary metabolites and plant hormones induced by different fungicides treatment in cotton plants. Pestic Biochem Physiol. 2017;142:117-22. https://doi.org/1 0.1016/j.pestbp.2017.04.001.

82. Rehman M, Ullah S, Bao Y, Wang B, Peng D, Liu L. Light-emitting diodes: whether an efficient source of light for indoor plants? Environ Sci Pollut Res. 2017;24(32):24743-52. https://doi.org/10.1007/s11356-017-0333-3.

83. Türkan F, Atalar MN, Aras A, Gülçin I, Bursal E. ICP-MS and HPLC analyses, enzyme inhibition and antioxidant potential of Achillea schischkinii Sosn. Bioorg Chem. 2020;94:103333. https://doi.org/10.1016/j.bioorg.2019.103333.

84. Teixeira T, Vale R, Almeida R, Ferreira T, Guimarães L. Antioxidant potential and its correlation with the contents of phenolic compounds and flavonoids of methanolic extracts from different medicinal plants. Rev Virt Química. 2017;9(4):1546-59. https://doi.org/10.21577/1984-6835.20170090.

85. Martins N, Barros L, Santos-Buelga C, Ferreira IC. Antioxidant potential of two Apiaceae plant extracts: a comparative study focused on the phenolic composition. Ind Crop Prod. 2016;79:188-94. https://doi.org/10.1016/j. indcrop.2015.11.018.

86. Burke A, Hall GR, Yaari R, Fleisher A, Dougherty J, Young J, et al. Pocket reference to Alzheimer's disease management: springer; 2015.

87. Weller J, Budson A. Current understanding of Alzheimer's disease diagnosis and treatment. F1000Research. 2018;7.

88. Khalil AT, Ayaz M, Ovais M, Wadood A, Ali M, Shinwari ZK, et al. In vitro cholinesterase enzymes inhibitory potential and in silico molecular docking studies of biogenic metal oxides nanoparticles. Inorgan Nano Metal Chem. 2018:48(9):441-8. https://doi.org/10.1080/24701556.2019.1569686.

89. Uddin MS, Al Mamun A, Kabir MT, Jakaria M, Mathew B, Barreto GE, et al. Nootropic and anti-Alzheimer's actions of medicinal plants: molecular insight into therapeutic potential to alleviate Alzheimer's neuropathology. Mol Neurobiol. 2019;56(7):4925-44. https://doi.org/10.1007/s12035-018-1420-2.

90. Bahadori MB, Dinparast L, Zengin G, Sarikurkcu C, Bahadori S, Asghari B, et al. Functional components, antidiabetic, anti-Alzheimer's disease, and antioxidant activities of Salvia syriaca L. Int J Food Prop. 2017;20(8):1761-72. https://doi.org/10.1080/10942912.2016.1218893.

91. Korkina L. Phenylpropanoids as naturally occurring antioxidants: from plant defense to human health. Cell Mol Biol. 2007;53(1):15-25.

92. Rossi A, Ligresti A, Longo R, Russo A, Borrelli F, Sautebin L. The inhibitory effect of propolis and caffeic acid phenethyl ester on cyclooxygenase activity in $\mathrm{J774}$ macrophages. Phytomedicine. 2002;9(6):530-5. https://doi. org/10.1078/09447110260573164

93. Li X, Wang T, Zhou B, Gao W, Cao J, Huang L. Chemical composition and antioxidant and anti-inflammatory potential of peels and flesh from 10 different pear varieties (Pyrus spp.). Food Chem. 2014;152:531-8. https://doi. org/10.1016/j.foodchem.2013.12.010.

94. Pradhan S, Girish C. Hepatoprotective herbal drug, silymarin from experimental pharmacology to clinical medicine. Indian J Med Res. 2006; 124(5):491-504.

95. Lim ZX, Ling APK, Hussein S. Callus induction of Ocimum sanctum and estimation of its total flavonoids content. Asian J Agri Sci. 2009:1 (2):55-61.

96. Coricovac D, Soica C, Muntean D, Popovici RA, Dehelean CA, Hogea E. Assessment of the effects induced by two triterpenoids on liver mitochondria respiratory function isolated from aged rats. Rev Chim. 2015; 66:1707-10.

97. Liyanaarachchi GD, Samarasekera JKRR, Mahanama KRR, Hemalal KDP. Tyrosinase, elastase, hyaluronidase, inhibitory and antioxidant activity of Sri Lankan medicinal plants for novel cosmeceuticals. Ind Crop Prod. 2018;111: 597-605. https://doi.org/10.1016/j.indcrop.2017.11.019.

98. Boran R. Investigations of anti-aging potential of Hypericum origanifolium Willd. For skincare formulations. Ind Crop Prod. 2018;118:290-5. https://doi. org/10.1016/j.indcrop.2018.03.058.

99. Briganti S, Camera E, Picardo M. Chemical and instrumental approaches to treat hyperpigmentation. Pigment Cell Res. 2003;16(2):101-10. https://doi. org/10.1034/j.1600-0749.2003.00029.x.

100. Finkel T, Holbrook NJ. Oxidants, oxidative stress and the biology of ageing Nature. 2000;408(6809):239.
101. Gkogkolou P, Böhm M. Advanced glycation end products: key players in skin aging? Dermato-endocrinology. 2012;4(3):259-70. https://doi.org/10.41 61/derm.22028.

102. Harraan D. Aging: a theory based on free radical and radiation chemistry; 1955.

103. Hori YS, Kuno A, Hosoda R, Horio Y. Regulation of FOXOs and p53 by SIRT1 modulators under oxidative stress. PLoS One. 2013;8(9):e73875. https://doi. org/10.1371/journal.pone.0073875.

104. Torres-Guerrero E, Quintanilla-Cedillo MR, Ruiz-Esmenjaud J, Arenas R. Leishmaniasis: a review. F1000Research. 2017;(6).

105. Janaki AC, Sailatha E, Gunasekaran S. Synthesis, characteristics and antimicrobial activity of $\mathrm{ZnO}$ nanoparticles. Spectrochim Acta A Mol Biomol Spectrosc. 2015;144:17-22. https://doi.org/10.1016/.jsaa.2015.02.041.

106. Modena MM, Rühle B, Burg TP, Wuttke S. Nanoparticle characterization: what to measure? Adv Mater. 2019:31(32):1901556.

107. Vimala K, Sundarraj S, Paulpandi M, Vengatesan S, Kannan S. Green synthesized doxorubicin loaded zinc oxide nanoparticles regulates the Bax and $\mathrm{BCl}-2$ expression in breast and colon carcinoma. Process Biochem. 2014 49(1):160-72. https://doi.org/10.1016/j.procbio.2013.10.007.

108. Heim S, Mitelman F. Cancer cytogenetics: chromosomal and molecular genetic aberrations of tumor cells: Wiley; 2015. https://doi.org/10.1002/ 9781118795569

109. Alaraby M, Annangi B, Hernández A, Creus A, Marcos R. A comprehensive study of the harmful effects of $\mathrm{ZnO}$ nanoparticles using Drosophila melanogaster as an in vivo model. J Hazard Mater. 2015;296:166-74. https:// doi.org/10.1016/j.jhazmat.2015.04.053

110. Chen P, Wang H, He M, Chen B, Yang B, Hu B. Size-dependent cytotoxicity study of ZnO nanoparticles in HepG2 cells. Ecotoxicol Environ Saf. 2019;171: 337-46. https://doi.org/10.1016/j.ecoenv.2018.12.096.

111. Jan $H$, Khan MA, Usman H, Shah M, Ansir R, Faisal S, et al. The Aquilegia pubiflora (Himalayan columbine) mediated synthesis of nanoceria for diverse biomedical applications. RSC Adv. 2020;10(33):19219-31. https://doi. org/10.1039/DORA01971B

112. Pârvu M, Pârvu AE. Antifungal plant extracts. Sci Against Microbial Pathogens. 2011;2(13):1055-62.

\section{Publisher's Note}

Springer Nature remains neutral with regard to jurisdictional claims in published maps and institutional affiliations.

Ready to submit your research? Choose BMC and benefit from:

- fast, convenient online submission

- thorough peer review by experienced researchers in your field

- rapid publication on acceptance

- support for research data, including large and complex data types

- gold Open Access which fosters wider collaboration and increased citations

- maximum visibility for your research: over $100 \mathrm{M}$ website views per year

At $\mathrm{BMC}$, research is always in progress.

Learn more biomedcentral.com/submissions 